\title{
Article \\ Suitability of Habitats in Nepal for Dactylorhiza hatagirea Now and under Predicted Future Changes in Climate
}

\author{
Bikram Shrestha ${ }^{1,2, *(\mathbb{D})}$, Spyros Tsiftsis ${ }^{3} \mathbb{D}$, Deep Jyoti Chapagain ${ }^{4,5}$, Chhatra Khadka ${ }^{6} \mathbb{D}$, Prakash $B$ Battarai $^{4,7}$, \\ Neelima Kayastha Shrestha ${ }^{8}$, Marta Alicja Kolanowska ${ }^{1,9}$ and Pavel Kindlmann ${ }^{1,2} \mathbb{D}$
}

1 Department of Biodiversity Research, Global Change Research Institute CAS, Bělidla 986/4a, 60300 Brno, Czech Republic; marta.a.kolanowska@gmail.com (M.A.K.); pavel.kindlmann@centrum.cz (P.K.)

2 Institute for Environmental Studies, Faculty of Science, Charles University, Benátská 2, 12801 Prague, Czech Republic

3 Department of Forest and Natural Environment Sciences, International Hellenic University, GR-66100 Drama, Greece; stsiftsis@for.ihu.gr

4 Central Department of Botany, Tribhuvan University, Kirtipur 44618, Nepal; chapagaindeep@gmail.com (D.J.C.); light.bhattarai@gmail.com (P.B.)

5 Department of Food and Resource Economics, University of Copenhagen, 1165 Copenhagen, Denmark

6 Chitwan National Park, Department of National Parks and Wildlife Conservation, Government of Nepal Ministry of Forests and Environment, Kathmandu 44600, Nepal; chhatra10@gmail.com

7 Institute of Geographic Sciences and Natural Resources Research, Chinese Academy of Sciences, Beijing 100101, China

8 Natural Product Chemistry, School of Health and Allied Sciences, Pokhara University, Pokhara 33700, Nepal; neelima.kstha@gmail.com

check for updates

Citation: Shrestha, B.; Tsiftsis, S.; Chapagain, D.J.; Khadka, C.; Bhattarai, P.; Kayastha Shrestha, N.; Alicja Kolanowska, M.; Kindlmann, P. Suitability of Habitats in Nepal for Dactylorhiza hatagirea Now and under Predicted Future Changes in Climate. Plants 2021, 10, 467. https://doi.org/ 10.3390/plants10030467

Academic Editor: Giuseppe Fenu

Received: 21 January 2021

Accepted: 26 February 2021

Published: 2 March 2021

Publisher's Note: MDPI stays neutral with regard to jurisdictional claims in published maps and institutional affiliations.

Copyright: (c) 2021 by the authors. Licensee MDPI, Basel, Switzerland. This article is an open access article distributed under the terms and conditions of the Creative Commons Attribution (CC BY) license (https:/ / creativecommons.org/licenses/by/ $4.0 /)$.
9 Department of Geobotany and Plant Ecology, Faculty of Biology and Environmental Protection, University of Lodz, Banacha 12/16, 90-237 Lodz, Poland

* Correspondence: bikramone@gmail.com

\begin{abstract}
Dactylorhiza hatagirea is a terrestrial orchid listed in Appendix II of the Convention on International Trade in Endangered Species of Wild Fauna and Flora (CITES) and classified as threatened by International Union for Conservation of Nature (IUCN). It is endemic to the Hindu-Kush Himalayan region, distributed from Pakistan to China. The main threat to its existence is climate change and the associated change in the distribution of its suitable habitats to higher altitudes due to increasing temperature. It is therefore necessary to determine the habitats that are suitable for its survival and their expected distribution after the predicted changes in climate. To do this, we use Maxent modelling of the data for its 208 locations. We predict its distribution in 2050 and 2070 using four climate change models and two greenhouse gas concentration trajectories. This revealed severe losses of suitable habitat in Nepal, in which, under the worst scenario, there will be a 71-81\% reduction the number of suitable locations for D. hatagirea by 2050 and $95-98 \%$ by 2070 . Under the most favorable scenario, this reduction will be $65-85 \%$ by 2070 . The intermediate greenhouse gas concentration trajectory surprisingly would result in a greater reduction by 2070 than the worst-case scenario. Our results provide important guidelines that local authorities interested in conserving this species could use to select areas that need to be protected now and in the future.
\end{abstract}

Keywords: Dactylorhiza hatagirea; medicinal plant; Himalaya; Nepal; climate change; Orchidaceae

\section{Introduction}

The world is rapidly changing and, as a result, biodiversity is being affected in various ways [1]. In addition to habitat loss, which is characterized as the greatest threat to species [2], living creatures are also affected by the increase in human emissions of carbon dioxide due to burning fossil fuels and other greenhouse gases, which are causing climate change [1]. The potential effects of future climatic conditions on biodiversity have been widely investigated and a large number of publications exist that predict these 
effects on trees [3-10], medicinal herbaceous plants and shrubs [11-17], fungi [18], invasive plants [19,20], terrestrial orchids [21], etc.

Due to the expected increase in temperature, the suitable habitats of many species will only be available further north or at higher altitudes e.g., [19,22-25]. Those species that are not able to colonize these habitats before their present sites become unsuitable are likely to become extinct, e.g., alpine plants [11]. To assess the effects of climate change on species, the most widely used method is species distribution modelling (SDM), which links data on species distribution with environmental data and is able to predict potentially suitable areas and their changes over time [26,27].

It is expected that all areas in the world will be affected by climate change, but these effects will vary spatially [1]. Mountain ecosystems, particularly those at tropical latitudes, are considered ecologically sensitive and vulnerable to climate change [28]. The Himalayas are predicted to experience a rise in temperature of $5-6{ }^{\circ} \mathrm{C}$ and increase in precipitation by $20-30 \%$ by the end of the twenty-first century [29], making them one of the most threatened non-polar regions in the world [30]. Nepalese Himalayas are already being affected by rapid temperature increase and other environmental changes at both regional and local scales [30,31]. This alleviates some of the abiotic restrictions (for example, low temperature and water availability) on the activity and distributions of species [32]. Recent work has shown that the increasingly warmer climate conditions allow species to become established at higher altitudes (in the nival zone), which forms a species pool for lower altitudes [33] and may drive endemic species with restricted physiological ranges to extinction [34].

Members of the family Orchidaceae belong to the plant species expected to decline to a lesser or greater degree. Many of these plants, especially terrestrial orchids, depend on highly specific insect pollinators and complex mycorrhizal associations [35-38]. This makes them more vulnerable to any ecosystem degradation and increases the likelihood of their extinction. In addition, ignorance of these complex biological associations usually results in an overestimation of their potential distribution area based on SDMs [39-41].

Dactylorhiza hatagirea (D.Don) Soó is a terrestrial orchid commonly known as "Panchaunle" in Nepali. It is listed in Appendix II of the Convention on International Trade in Endangered Species of Wild Fauna and Flora (CITES). It is classified as a critically endangered species by the Conservation Assessment and Management Plan [42] and categorized as threatened by the International Union for Conservation of Nature (IUCN); [43]. Moreover, it is considered as an endangered and strictly protected species in list I of the Government of Nepal [44]. It is endemic to the Hindu-Kush Himalayan region and distributed from Pakistan to China [45]. The species occurs patchily, in very low densities of 0.1 to 2.18 individuals $/ \mathrm{m}^{2}$ [46-49].

Dactylorhiza hatagirea grows in the pastures in the sub-alpine and alpine zones at altitudes of $2800-4200 \mathrm{~m}$ [50]. It is considered to be highly valuable medicinal species in Nepal. The tubers of this orchid are used for treating diabetes, dysentery, colic pain, seminal weakness, and diarrhea, and as an aphrodisiac [51-53]. More recent findings indicate that $D$. hatagirea also has anti-cancerous properties [54].

Due to its medicinal properties, this species has been heavily exploited. Overexploitation, illegal trade, habitat destruction, and climate change are thus major threats to its survival [46]. D. hatagirea is also a good indicator of environmental quality [55]. This indicates the need to establish areas where this species will be able to survive, thus enhancing its conservation and restoration [56,57]. Therefore, information about its habitats is particularly important for ensuring its proper management and protection.

In Nepal, only a few studies have focused on the abundance, density, and conservation of $D$. hatagirea $[46,47,58]$, and only one on suitable habitat modelling [59]. Possible effects of climate change on its distribution have yet to be explored. Kunwar et al. [59] use bioclimatic variables and slope as predictors for identifying suitable habitats. However, they rely mostly on herbarium data, not on data collected directly in the field. In addition, they ignore geological substrate and soil properties, which are important factors determining habitat suitability for terrestrial orchids [60]. Finally, they make only an analysis of the 
current state and make no predictions for the future potential distribution of $D$. hatagirea under climate change.

Our study differs from Kunwar et al. [59] by:

(a) using recent data from field excursions;

(b) mapping the potential suitable habitat using more predictors than Kunwar et al. [59] by adding geological substrate and soil properties, which makes the predictions more realistic;

(c) making predictions about how the current potential distribution of this species will change under future climate change scenarios.

This is a large step forward compared to the stage set by Kunwar et al. [59]. Our results will help local authorities to effectively manage the conservation of the endangered D. hatagirea.

\section{Results}

\subsection{Environmental Variables Associated with the Localities Where D. hatagirea Currently Occurs}

Although the initial dataset contained a large number of localities for D. hatagirea (208 microsites), only 44 grid cells were occupied. This number of locations and grid cells is sufficient for almost all modelling techniques. In general, a sample size of c. 40-50 records (grids) provides robust models. Moreover, Maxent model produced good models even with smaller sample sizes [61,62].

The values of Pearson's correlation coefficients between the bioclimatic variables are presented in Table 1. After omitting the variables with a high intercorrelation $(\mathrm{r}>|0.80|)$, those included in the Maxent software were the annual mean temperature (BIO1), the mean diurnal range (BIO2), the temperature seasonality (BIO4), the annual precipitation (BIO12), the precipitation seasonality (BIO15), the precipitation in the driest quarter (BIO17), and the precipitation in the coldest quarter (BIO19).

Table 1. Pearson's correlation coefficients among the 19 bioclimatic variables (correlations with $\mathrm{r} \geq|0.80|$ are shown in bold).

\begin{tabular}{|c|c|c|c|c|c|c|c|c|c|c|c|c|c|c|c|c|c|c|c|}
\hline & Bio1 & Bio2 & Bio3 & Bio4 & Bio5 & Bio6 & Bio7 & Bio8 & Bio9 & Bio10 & Bio11 & Bio12 & Bio13 & Bio14 & Bio15 & Bio16 & Bio17 & Bio18 & Bio19 \\
\hline Bio1 & 0 & -0.04 & 0.62 & -0.69 & 0.99 & 0.99 & -0.58 & 0.98 & 0.96 & 0.99 & 0.99 & 0.78 & 0.84 & -0.16 & 0.78 & 0.83 & -0.06 & 0.69 & -0.66 \\
\hline Bio2 & 0 & 0 & 0.19 & 0.32 & 0.05 & -0.13 & 0.54 & -0.03 & -0.04 & 0.003 & -0.08 & -0.18 & -0.10 & -0.33 & 0.01 & -0.11 & -0.15 & -0.24 & -0.03 \\
\hline Bio3 & 0 & 0 & 0 & -0.81 & 0.56 & 0.67 & -0.68 & 0.55 & 0.49 & 0.56 & 0.67 & 0.55 & 0.51 & 0.10 & 0.32 & 0.54 & 0.15 & 0.51 & -0.47 \\
\hline Bio4 & 0 & 0 & 0 & 0 & -0.59 & -0.78 & 0.95 & -0.61 & -0.57 & -0.61 & -0.75 & -0.65 & -0.57 & -0.25 & -0.31 & -0.60 & -0.20 & -0.63 & 0.49 \\
\hline Bio5 & 0 & 0 & 0 & 0 & 0 & 0.96 & -0.46 & 0.97 & 0.96 & 0.99 & 0.97 & 0.77 & 0.82 & -0.23 & 0.81 & 0.81 & -0.11 & 0.66 & -0.66 \\
\hline Bio6 & 0 & 0 & 0 & 0 & 0 & 0 & -0.69 & 0.96 & 0.93 & 0.97 & 0.99 & 0.82 & 0.83 & -0.08 & 0.73 & 0.82 & -0.01 & 0.72 & -0.64 \\
\hline Bio7 & 0 & 0 & 0 & 0 & 0 & 0 & 0 & -0.51 & -0.47 & -0.50 & -0.65 & -0.60 & -0.51 & -0.33 & -0.25 & -0.54 & -0.26 & -0.60 & 0.36 \\
\hline Bio8 & 0 & 0 & 0 & 0 & 0 & 0 & 0 & 0 & 0.95 & 0.98 & 0.96 & 0.79 & 0.83 & -0.18 & 0.81 & 0.82 & -0.09 & 0.69 & -0.65 \\
\hline Bio9 & 0 & 0 & 0 & 0 & 0 & 0 & 0 & 0 & 0 & 0.97 & 0.94 & 0.76 & 0.81 & -0.22 & 0.78 & 0.79 & -0.13 & 0.65 & -0.61 \\
\hline Bio10 & 0 & 0 & 0 & 0 & 0 & 0 & 0 & 0 & 0 & 0 & 0.98 & 0.79 & 0.83 & -0.21 & 0.81 & 0.82 & -0.09 & 0.67 & -0.65 \\
\hline Bio11 & 0 & 0 & 0 & 0 & 0 & 0 & 0 & 0 & 0 & 0 & 0 & 0.81 & 0.83 & -0.11 & 0.74 & 0.82 & -0.03 & 0.71 & -0.66 \\
\hline Bio12 & 0 & 0 & 0 & 0 & 0 & 0 & 0 & 0 & 0 & 0 & 0 & 0 & 0.97 & -0.03 & 0.74 & 0.98 & -0.10 & 0.95 & -0.61 \\
\hline Bio13 & 0 & 0 & 0 & 0 & 0 & 0 & 0 & 0 & 0 & 0 & 0 & 0 & 0 & -0.14 & 0.84 & 0.99 & -0.18 & 0.91 & -0.64 \\
\hline Bio14 & 0 & 0 & 0 & 0 & 0 & 0 & 0 & 0 & 0 & 0 & 0 & 0 & 0 & 0 & -0.41 & -0.13 & 0.81 & -0.03 & 0.54 \\
\hline Bio15 & 0 & 0 & 0 & 0 & 0 & 0 & 0 & 0 & 0 & 0 & 0 & 0 & 0 & 0 & 0 & 0.82 & -0.38 & 0.67 & -0.67 \\
\hline Bio16 & 0 & 0 & 0 & 0 & 0 & 0 & 0 & 0 & 0 & 0 & 0 & 0 & 0 & 0 & 0 & 0 & -0.18 & 0.94 & -0.66 \\
\hline Bio17 & 0 & 0 & 0 & 0 & 0 & 0 & 0 & 0 & 0 & 0 & 0 & 0 & 0 & 0 & 0 & 0 & 0 & -0.19 & 0.67 \\
\hline Bio18 & 0 & 0 & 0 & 0 & 0 & 0 & 0 & 0 & 0 & 0 & 0 & 0 & 0 & 0 & 0 & 0 & 0 & 0 & -0.63 \\
\hline Bio19 & 0 & 0 & 0 & 0 & 0 & 0 & 0 & 0 & 0 & 0 & 0 & 0 & 0 & 0 & 0 & 0 & 0 & 0 & 0 \\
\hline
\end{tabular}

Abbreviations: Bio1 = annual mean temperature; Bio2 = mean diurnal range; Bio3 = isothermality; Bio4 = temperature seasonality; Bio5 = maximum temperature in the warmest month; Bio6 $=$ minimum temperature in the coldest month; Bio7 = temperature annual range; $\mathrm{Bio} 8=$ mean temperature in the wettest quarter; $\mathrm{Bio} 9=$ mean temperature in the driest quarter; $B$ Bio $10=$ mean temperature in the warmest quarter; Bio11 = mean temperature in the coldest quarter; Bio12 = annual precipitation; Bio13 = precipitation of the wettest month; Bio14 = precipitation of the driest month; Bio15 = precipitation seasonality; Bio16 = precipitation of the wettest quarter; Bio17 = precipitation of the driest quarter; Bio18 = precipitation of the warmest quarter; Bio19 = precipitation of the coldest quarter.

The jackknife test indicated that annual mean temperature (BIO1), precipitation seasonality (BIO15), and annual precipitation (BIO12) are the most significant variables, whereas temperature seasonality (BIO4) and the mean diurnal range (BIO2) were the least significant. The precipitation in the driest quarter (BIO17), the precipitation in the coldest quarter (BIO19), and the environmental layer of the parent material, as generated from the Soil and Terrain Database (SOTER) of Nepal, were of intermediate significance (Figure 1). Omitting precipitation seasonality (BIO15) from the model causes the largest loss in the 
explanatory power of the model, compared with omitting any of the remaining variables. Mean diurnal range (BIO2) and temperature seasonality (BIO4) by themselves are not useful for estimating the distribution of $D$. hatagirea.

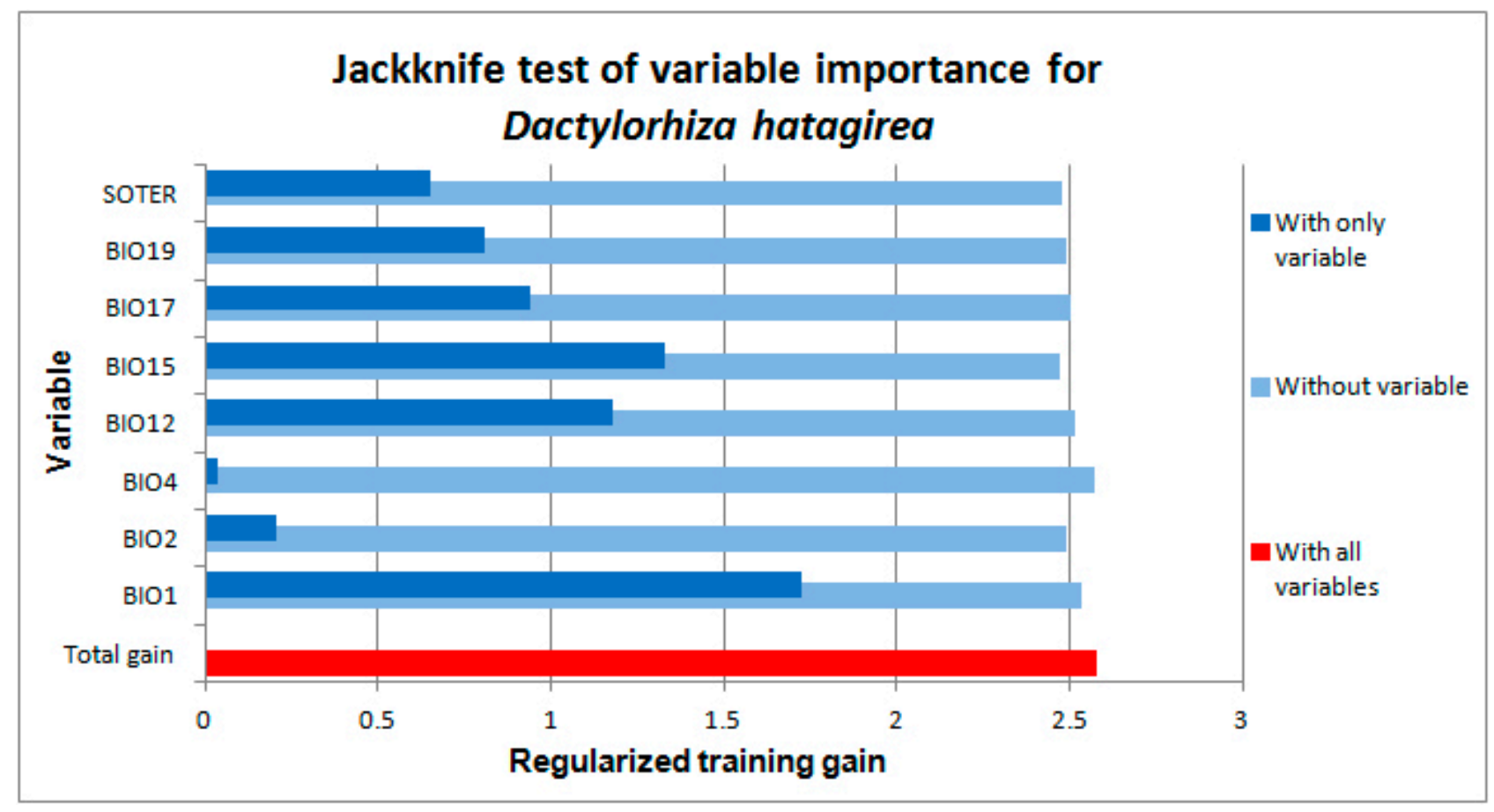

Figure 1. Results of the jackknife test of the importance of the environmental variables to be used in the development of the Maxent model of Dactylorhiza hatagirea. The length of the dark-blue bar indicates the size of the impact of the selected variable, and the length of light-blue bar shows how much of the explanatory power of the model would be lost if the corresponding factor were excluded from the analysis. See Table 1 for full names of the variables on the y-axis.

\subsection{Distribution and Habitat Suitability of D. hatagirea under Current Climate and Various Future Climate Change Scenarios}

The current potential distribution predicted by the Maxent model is shown in Figure 2. Grid cells with habitat suitability values for $D$. hatagirea below the lowest presence threshold $(\mathrm{LPT}=0.335)$ are unsuitable areas (blue and green colors). Under current climate conditions, the potentially suitable habitats are located in the districts Darchula, Bhajang, Dolpa, Magdi, Mustang, Manang, Kaski, Gorkha, Rasuwa, Sindhupalchok, Dolakha, Sholukhumbu, and Sankhuwasabha in Nepal. That is, there is an area of $10,839 \mathrm{~km}^{2}$ with a suitability index larger than 0.2 (Figure 2). In Kunwar et al. [59], some additional areas, covering $25,479 \mathrm{~km}^{2}$, are reported as being suitable: Bajung, Kalikot, Humla, Mugu, Jumla, Rukum, and Taplejung. Under future climate scenarios (Figures 3-5), it is expected that suitable habitats will only remain in Dolpa region. However, the suitable areas will then include the districts Mugu and Humla (Figures 3-5) and the total range of very highly suitable areas covers c. 1700 grid cells under RCP4.5 in 2070 under the BCC-CSM1-1 model (Figure 3). All of the suitable habitats (both current and new) will be collapsed in the HadGEMM2-ES model (Figure 6). 


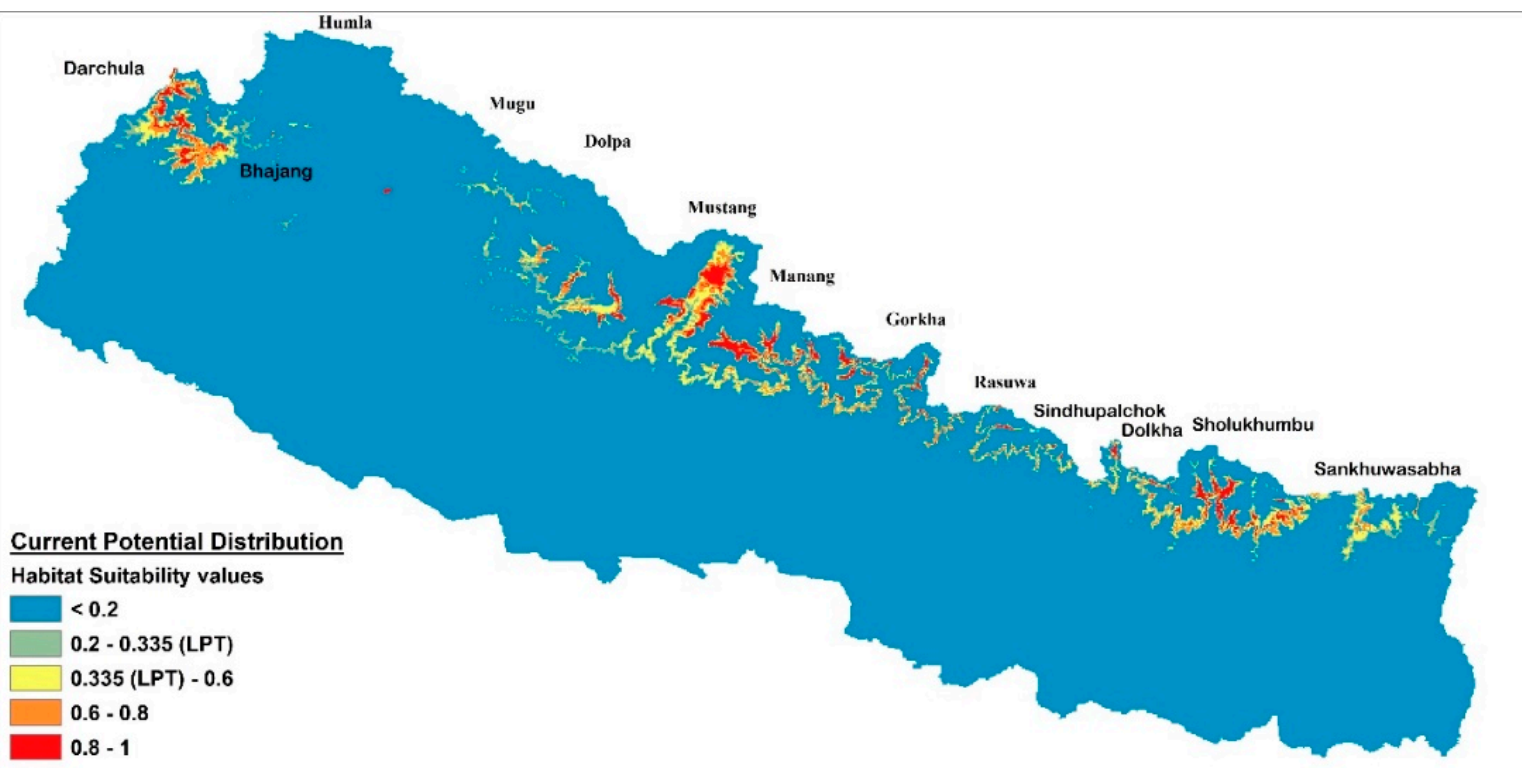

Figure 2. Predicted current potential distribution of habitats of different suitability in Nepal based on current climatic conditions. The values 0.2-0.335 (grey colour) indicate low suitability (below the lowest presence threshold), 0.335-0.6 (yellow colour) medium suitability, 0.6-0.8 (orange colour) high suitability, and 0.8-1 (red colour) very high suitability areas.

Figures for each climate change model are shown below.

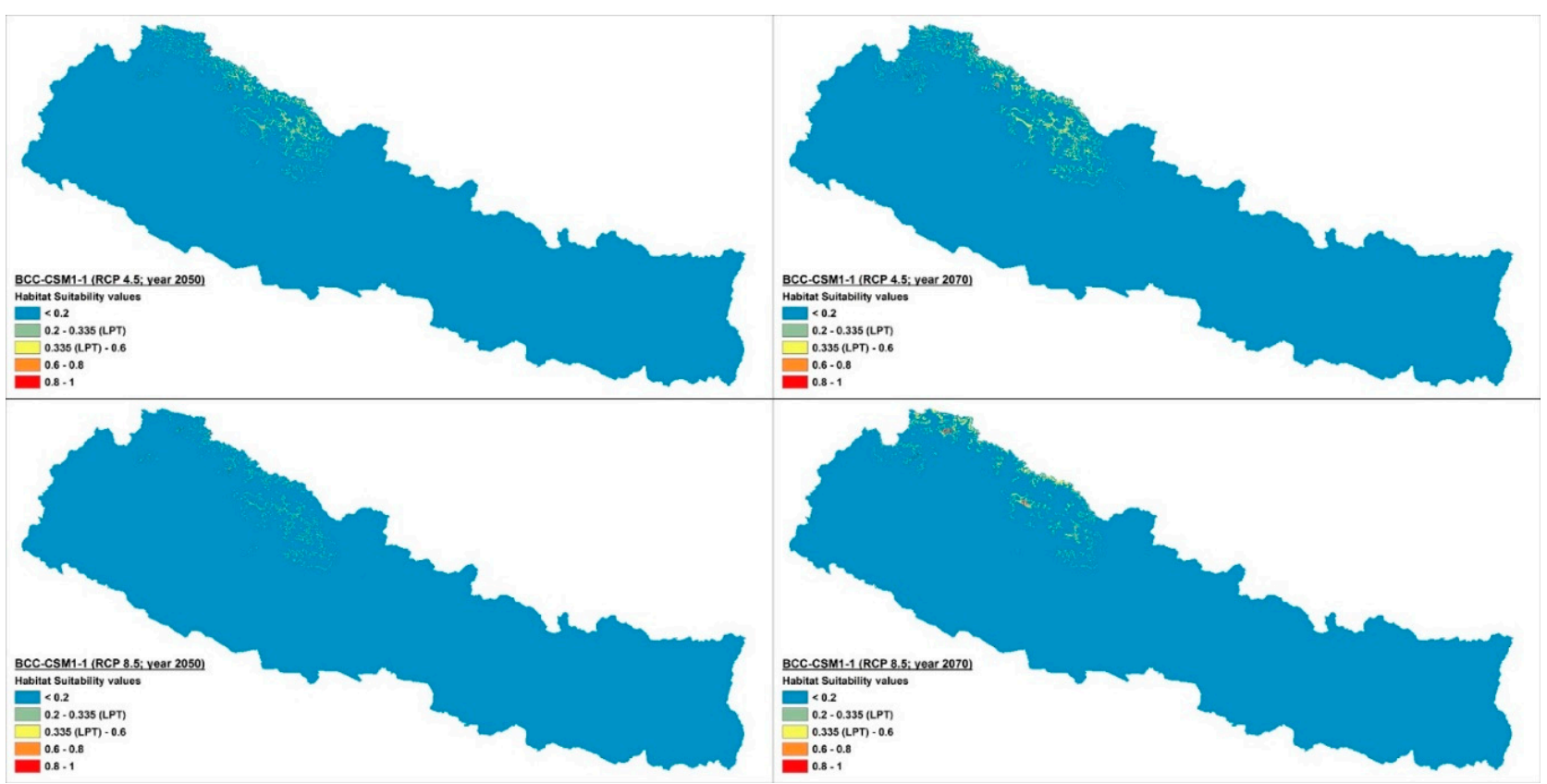

Figure 3. Climate change scenario under BCC-CSM1 model, RCP 4.5 and 8.5 at 2050 and 2070. 


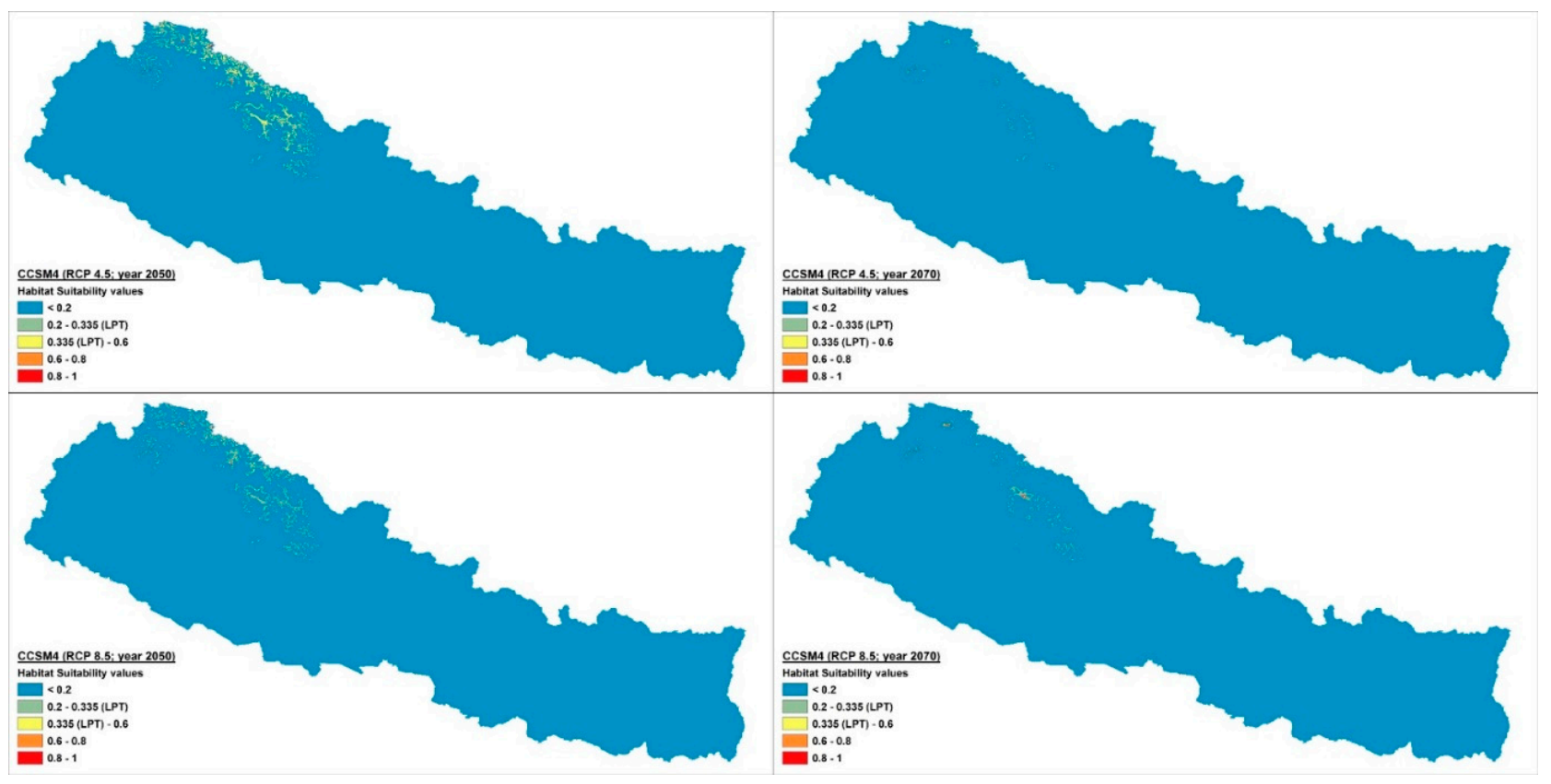

Figure 4. Climate change scenario under CCSM4 model, RCP 4.5 and 8.5 at 2050 and 2070.
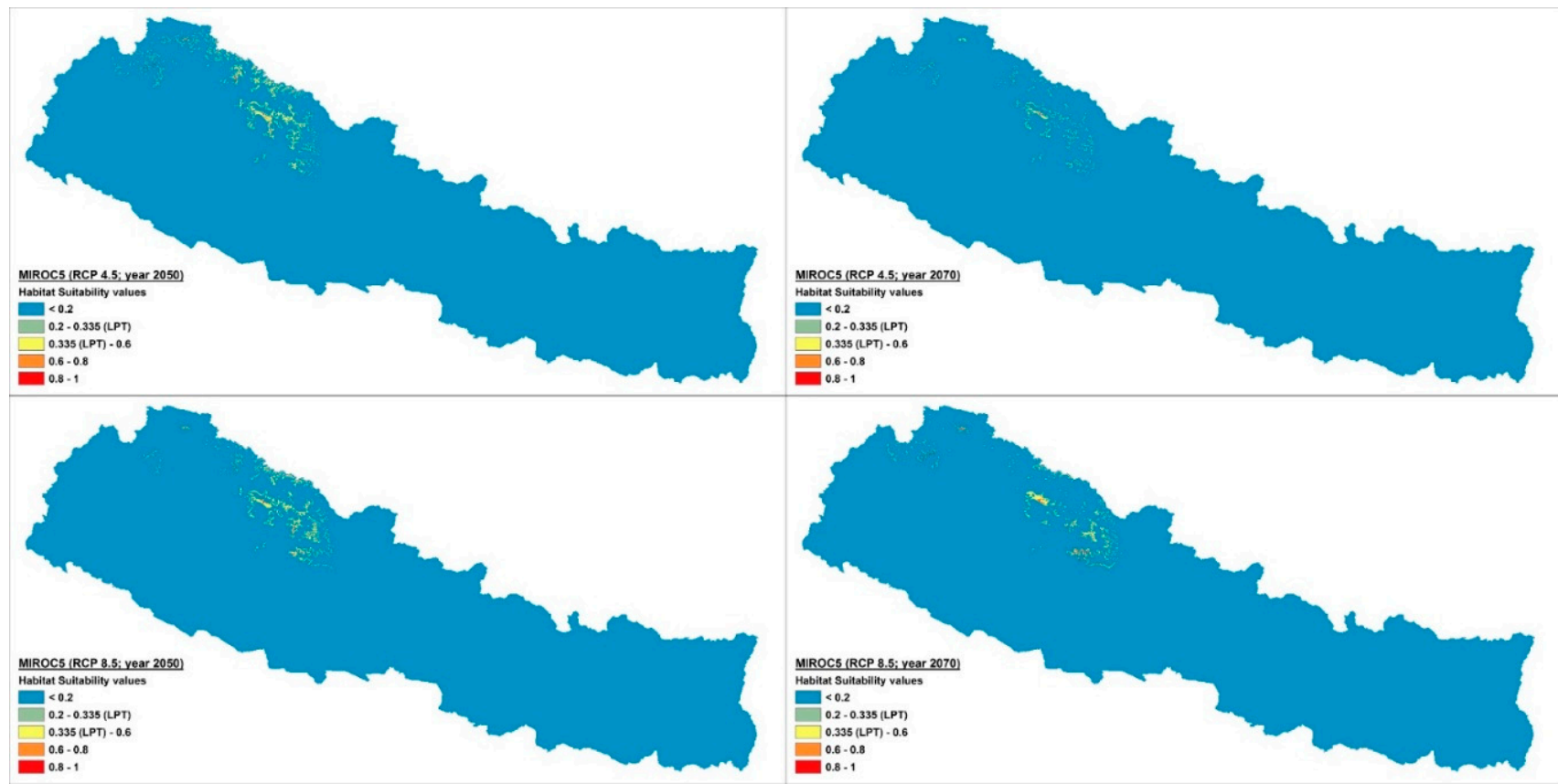

Figure 5. Climate change scenario under MIROC5 model, RCP 4.5 and 8.5 at 2050 and 2070. 


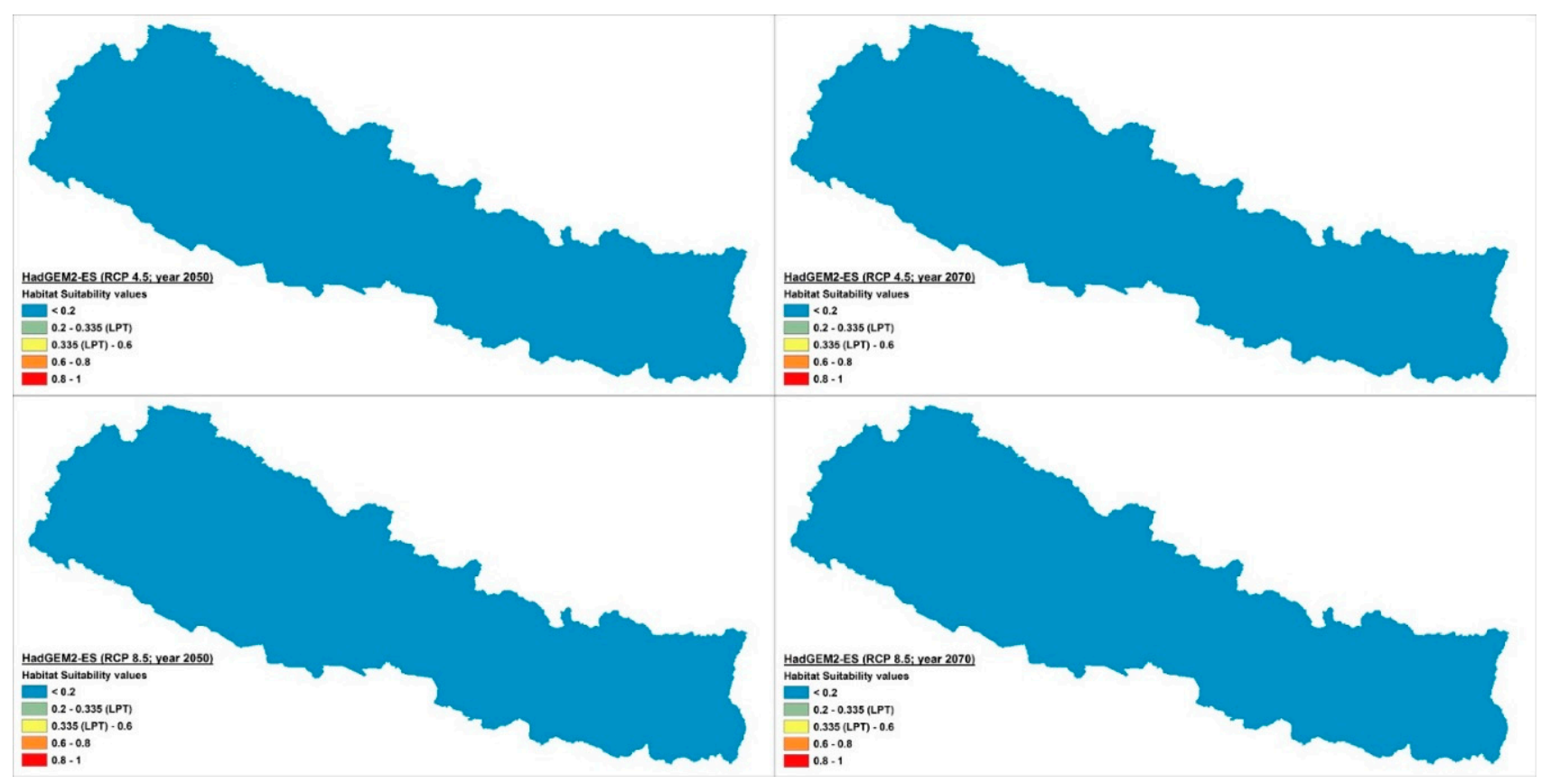

Figure 6. Climate change scenario under HadGEM2-ESmodel, RCP 4.5 and 8.5 at 2050 and 2070.

2.3. Numbers of Suitable Grid Cells of D. hatagirea under Current Climate vs. Those under Different Future Climate Change Scenarios

Under current climatic conditions, the habitat suitability values of 7731 grid cells were above the lowest presence threshold $(\mathrm{LPT}=0.335)$ (Figure 7 ), whereas under the future climate scenarios, the number of grid cells with potentially suitable habitats falls dramatically, reaching a maximum of ca. 1700 grid cells in 2070 under BCC-CSM1- 1 (RCP4.5) scenario (Figures 3 and 8b). Contrary to other climate change models, the Hadley Earth System Model (HadGEM2-ES) predicts the collapse of almost all suitable habitats under all four types of climate change scenarios (Figures 6 and 8).

In RCP4.5, the numbers of grid cells containing suitable habitats ranged from 0 to 1596 in 2050 and from 0 to 1696 in 2070 in all four models of the climate change scenario considered here. In RCP8.5, this range was 0 to 949 in 2050 and 0 to 1043 in 2070. On average, there were less than 1600 grid cells containing suitable habitats in 2050 and 1700 in 2070 . 


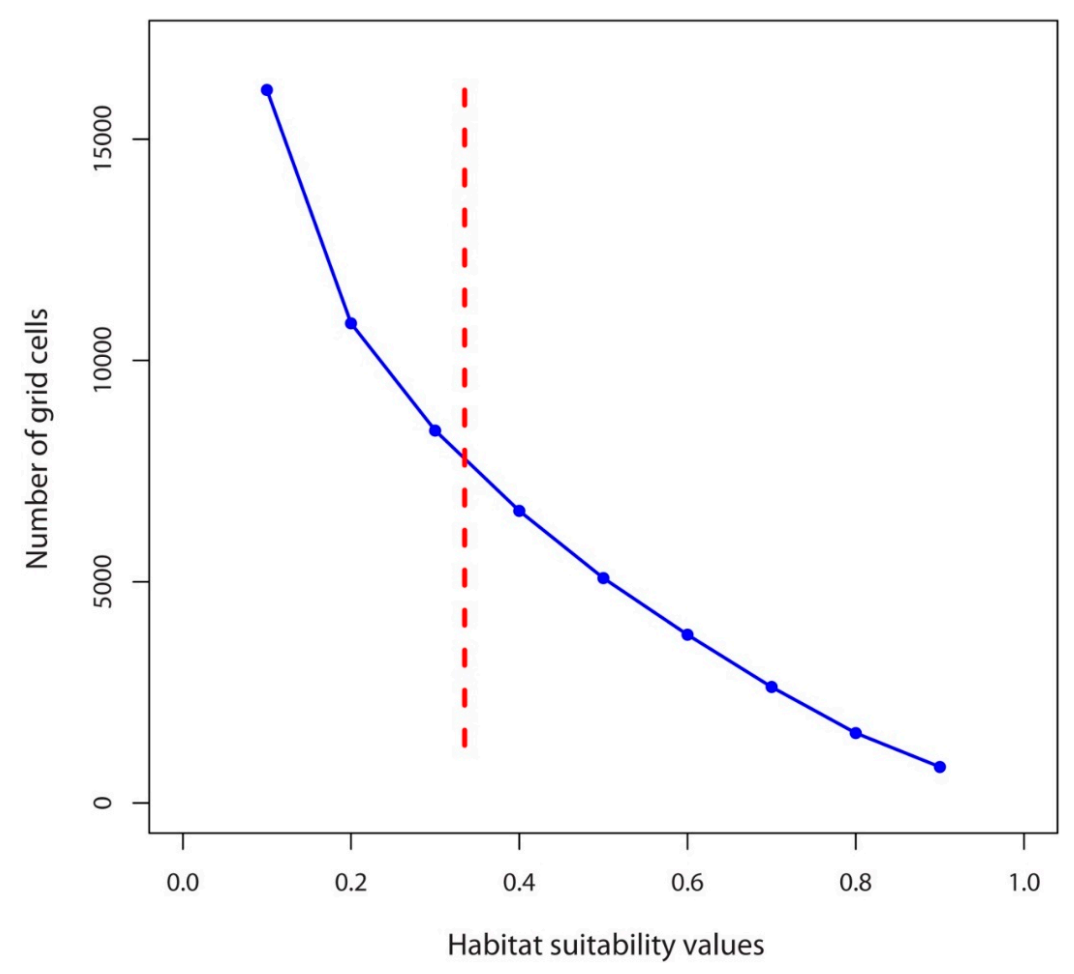

Figure 7. The current number of grid cells in Nepal with particular habitat suitability values. The dashed vertical red line is the lowest presence threshold $(\mathrm{LPT}=0.335)$.
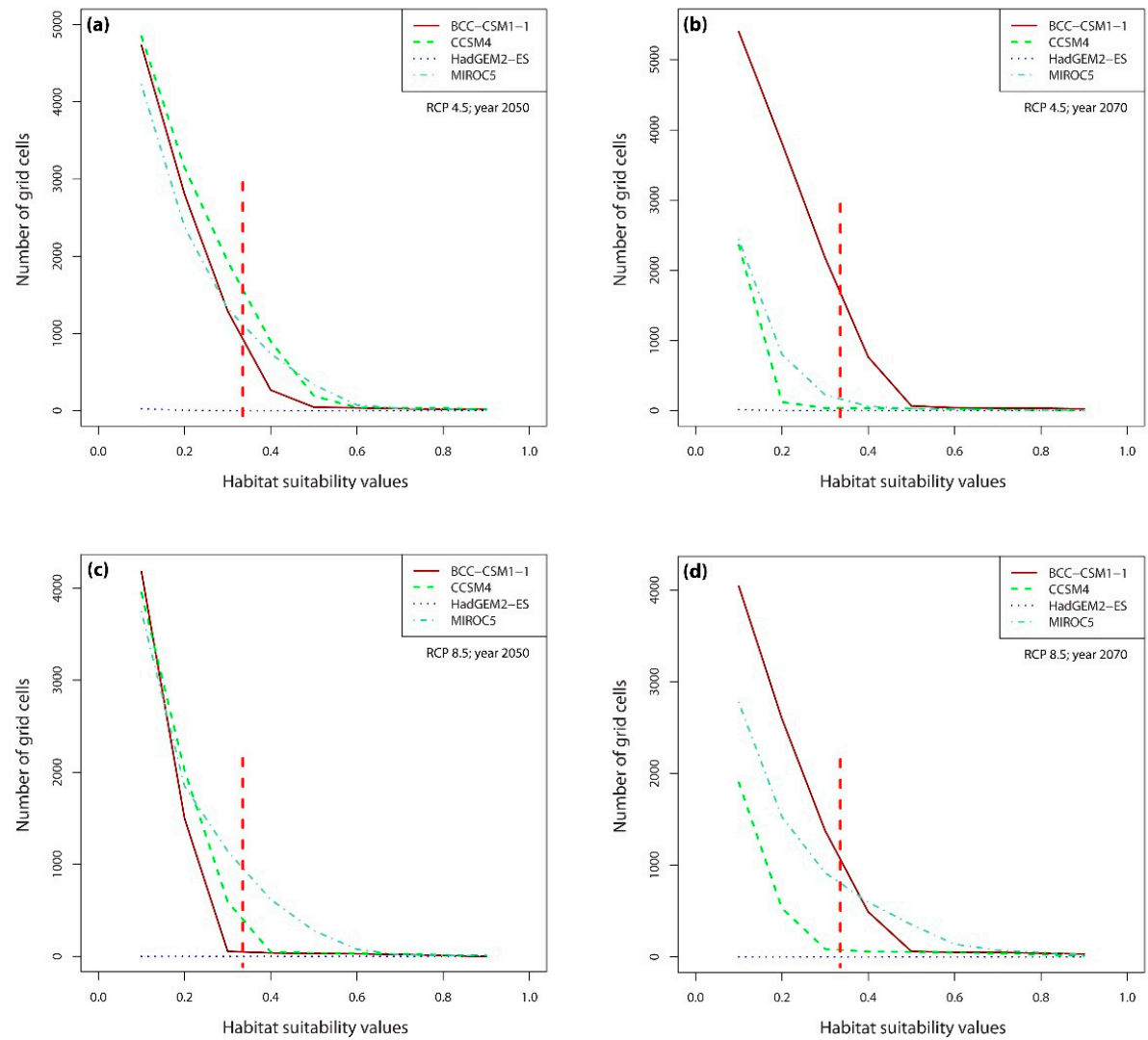

Figure 8. The number of grid cells in Nepal with particular habitat suitability values predicted for 2050 according to RCP4.5 (a) and RCP8.5 (c) and 2070 according to RCP4.5 (b) and RCP8.5 (d), based on four climate change models (see inset). The dashed vertical red line is the lowest presence threshold $(\mathrm{LPT}=0.335)$. 
2.4. Percentage Change in Habitat Suitability of D. hatagirea under Current Climate and under Different Future Climate Change Scenarios

Considering coverage of suitable habitats, the studied species will lose all preferred niches by 2070 in HadGEM2-ES RCP4.5 and RCP8.5 scenarios. Based on CCSM4 simulation, it will lose $71-81 \%$ of its niches by 2050 and $95-98 \%$ by 2070 (Table 2, Figures 9 and 10). The most favorable for D. hatagirea is the BCC-CSM1-1 model. However, even in this scenario the orchid will lose $65-85 \%$ of its suitable habitats (Table 2). Surprisingly, the RCP.4.5 pathway seems to be more harmful for D. hatagirea occurrence in 2070 than RCP8.5.

Table 2. Change in the coverage $\left(\mathrm{km}^{2}\right)$ of suitable niches of $D$. hatagirea in response to various climate change scenarios.

\begin{tabular}{|c|c|c|c|c|c|c|c|}
\hline Model & Year & $\begin{array}{c}\text { RCP } \\
\text { Pathway }\end{array}$ & $\begin{array}{l}-1 \text { (Range } \\
\text { Expansion) }\end{array}$ & $\begin{array}{l}0 \text { (Absence } \\
\text { in Both) }\end{array}$ & $\begin{array}{l}1 \text { (Present in } \\
\text { Both) }\end{array}$ & $\begin{array}{c}2 \text { (Range } \\
\text { Contraction) }\end{array}$ & $\begin{array}{c}\text { Coverage } \\
\text { Change }\end{array}$ \\
\hline \multirow{4}{*}{ BCC-CSM1-1 } & \multirow{2}{*}{2050} & 4.5 & $2,085,974$ & $136,487,198$ & 3805 & $8,143,194$ & $-74.35 \%$ \\
\hline & & 8.5 & $1,133,826$ & $137,439,346$ & 12,366 & $8,134,633$ & $-85.93 \%$ \\
\hline & \multirow{2}{*}{2070} & 4.5 & $2,818,395$ & $135,754,777$ & 15,219 & $8,131,780$ & $-65.22 \%$ \\
\hline & & 8.5 & $1,890,028$ & $136,683,145$ & 12,366 & $8,134,633$ & $-76.65 \%$ \\
\hline \multirow{4}{*}{ CCSM4 } & \multirow{2}{*}{2050} & 4.5 & $2,330,432$ & $136,242,741$ & 3805 & $8,143,194$ & $-71.35 \%$ \\
\hline & & 8.5 & $1,502,891$ & $137,070,282$ & 1902 & $8,145,096$ & $-81.53 \%$ \\
\hline & \multirow{2}{*}{2070} & 4.5 & 91,315 & $138,481,858$ & 0951 & $8,146,048$ & $-98.87 \%$ \\
\hline & & 8.5 & 389,991 & $138,183,182$ & 5707 & $8,141,292$ & $-95.14 \%$ \\
\hline \multirow{4}{*}{ HadGEM2-ES } & \multirow{2}{*}{2050} & 4.5 & 4756 & $138,568,416$ & 0 & $8,146,999$ & $-99.94 \%$ \\
\hline & & 8.5 & 0 & $138,573,172$ & 0 & $8,146,999$ & $-100.00 \%$ \\
\hline & \multirow{2}{*}{2070} & 4.5 & 0 & $138,573,172$ & 0 & $8,146,999$ & $-100.00 \%$ \\
\hline & & 8.5 & 0 & $138,573,172$ & 0 & $8,146,999$ & $-100.00 \%$ \\
\hline \multirow{4}{*}{ MIROC5 } & \multirow{2}{*}{2050} & 4.5 & $1,776,835$ & $136,796,337$ & 3805 & $8,143,194$ & $-78.14 \%$ \\
\hline & & 8.5 & $1,385,893$ & $137,187,279$ & 8561 & $8,138,438$ & $-82.88 \%$ \\
\hline & \multirow{2}{*}{2070} & 4.5 & 605,912 & $137,967,260$ & 3805 & $8,143,194$ & $-92.52 \%$ \\
\hline & & 8.5 & $1,122,412$ & $137,450,760$ & 16,170 & $8,130,828$ & $-86.02 \%$ \\
\hline
\end{tabular}



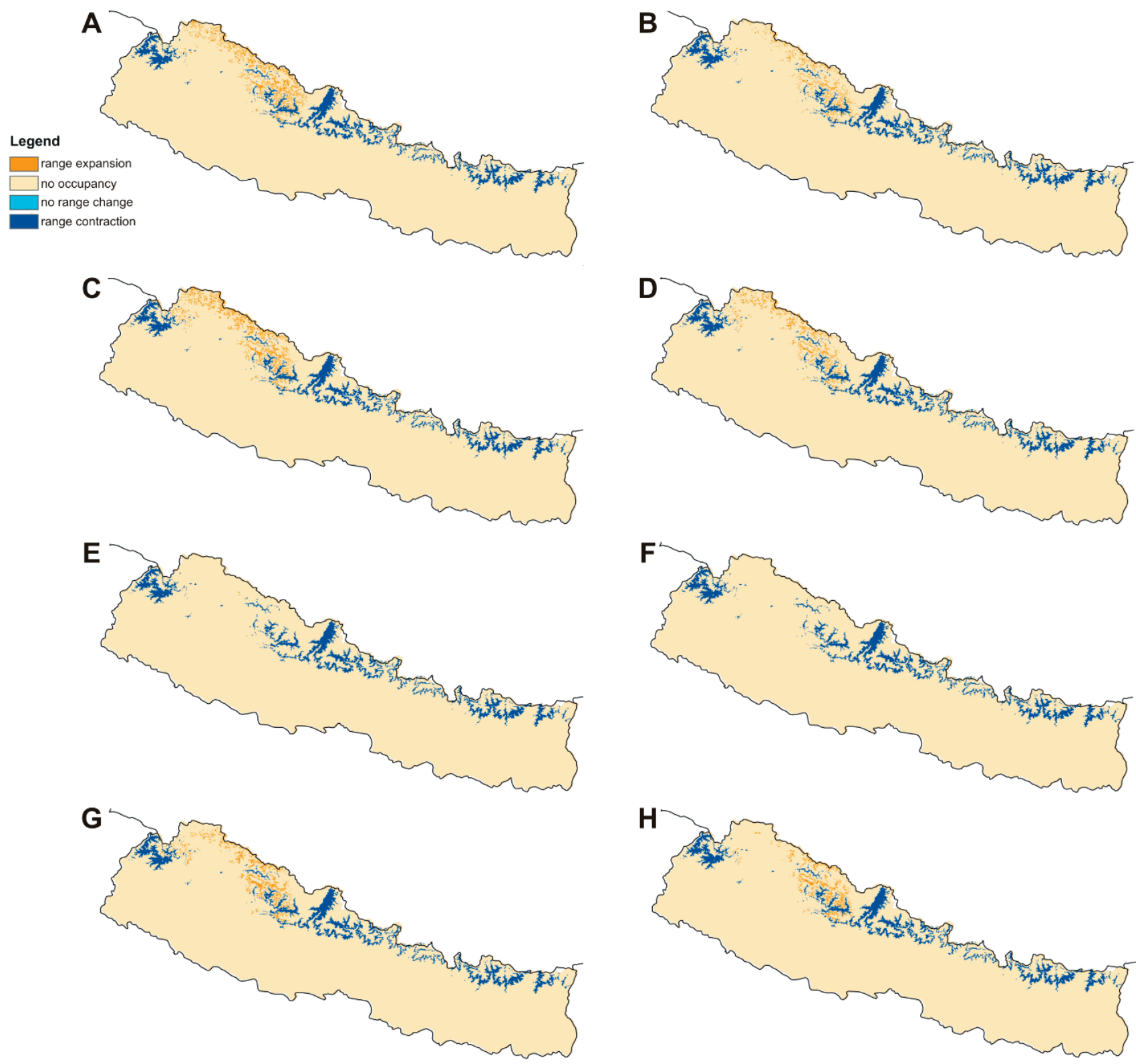

Figure 9. Changes in the distribution of suitable niches of Dactylorhiza hatagirea in 2050 according to RCP4.5 (A,C,E,G) and RCP8.5 (B,D,F,H) climate change scenarios. (A,B), BCC-CSM1-1 model; (C,D), CCSM4 model; (E,F), HadGEM2-ES model; $(\mathbf{G}, \mathbf{H})$, MIROC5 model. 

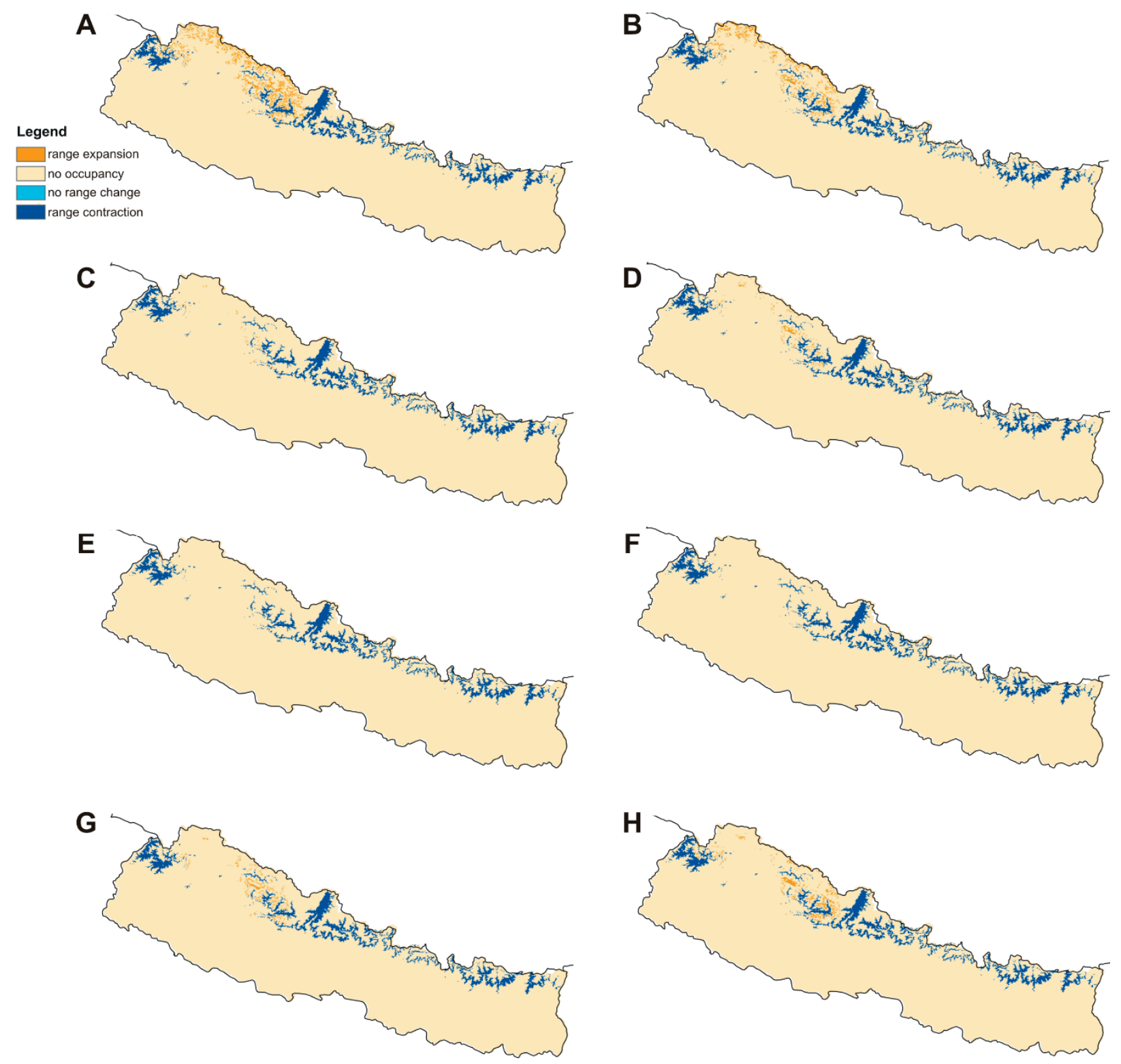

Figure 10. Changes in the distribution of suitable niches of Dactylorhiza hatagirea in 2070 according to RCP4.5 (A,C,E,G) and RCP8.5 (B,D,F,H) climate change scenarios. (A,B), BCC-CSM1-1 model; (C,D), CCSM4 model; (E,F), HadGEM2-ES model; $(\mathbf{G}, \mathbf{H})$, MIROC5 model.

2.5. Change in Altitude of Potential Suitable Areas of D. hatagirea under Current Climate and under Different Future Climate Change Scenarios

Under the current climatic conditions, the potentially suitable areas for D. hatagirea are located between 2300 and 5000 m. a.s.l., whereas the average altitude is at ca. $4000 \mathrm{~m}$ (Figure 11). Under future climate change scenarios, it is expected that $D$. hatagirea will shift towards higher altitudes, reaching up to $6000 \mathrm{~m}$ a.s.l., whereas the average altitude will be ca. $5000 \mathrm{~m}$ (Figure 12). 


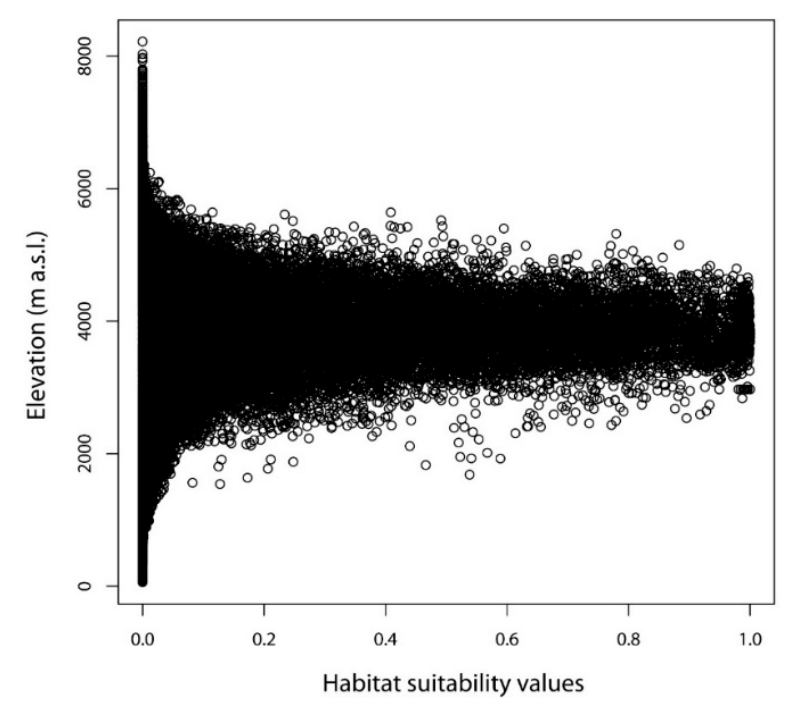

Figure 11. Altitude of the potential suitable areas under current climate conditions.

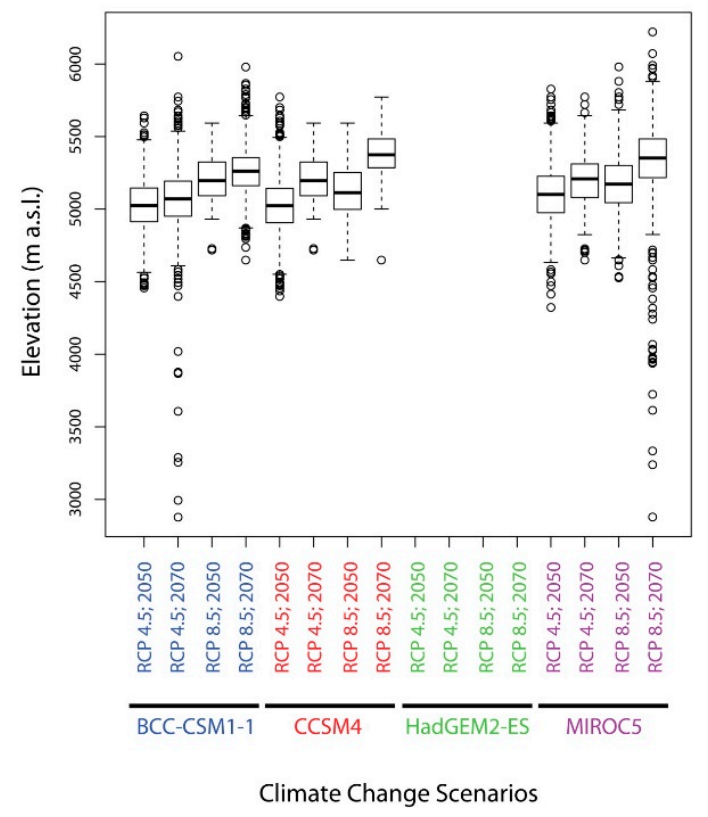

Figure 12. Elevational range of the grid cells where $D$. hatagirea was predicted as present (habitat suitability values $\geq 0.335$ ) under the different climate change scenarios.

\section{Discussion}

The export of medicinal species from Nepal to China began in the late 1990s, and continues today [63]. Although orchids in Nepal are protected according to local legal acts (Forest Act 1993, Forest Regulations 1995, and amendment in 2001), contradicting its own policies, the Government of Nepal published a notification on 14th April 2008 permitting collection of wild orchids for trade [64]. The absence of clear regulations on sustainable harvesting and insufficient implementation of policies recently caused an increase in the illegal trade of orchids $[64,65]$. In addition to the direct destruction of D. hatagirea populations for commerce, Bhattarai et al. [46] found grazing, trampling, number of cattle, and distance to settlement as the main anthropogenic factors negatively affecting the population condition of this orchid. As indicated in our study, the survival chances of the orchid will be further reduced by climate change. Our analyses indicate severe habitat loss in Nepal and, in the worst-case scenario, all suitable niches of $D$. hatagirea will disappear. 
Current suitable habitats for D. hatagirea suggested by Kunwar et al. [59] are greater than ours. This is most likely because Kunwar et al. [59] used only a subset of the predicting variables used here. Although climatic factors are not the only factors determining habitat suitability [66], Kunwar et al. [59] did not consider soil properties (identified as being of intermediate significance here).

The other result of our analyses is a predicted change in altitudinal distribution of $D$. hatagirea. Based on the environmental predictors used in the analyses (bioclimatic variables, soil type), the distribution of $D$. hatagirea was found to be mainly climate driven because the total gain of Maxent model was greatly influenced by temperature and precipitation. Thus, it is expected that $D$. hatagirea will shift towards areas of higher altitude. Specifically, the currently observed average vertical range of this species is $4000 \mathrm{~m}$, whereas in the future the average altitude of the studied orchid will be elevated to $5000 \mathrm{~m}$. This trend of moving uphill was already found in other plants inhabiting mountain slopes [67]. However, it is important to notice that species abundance can also change and lead to altered dynamics in the plant communities in the plant communities [68]. This might also be the case of $D$. hatagirea, which-like all orchids-is also sensitive to the increased competition. Thus, climate change may also affect $D$. hatagirea indirectly, through the change in the competition equilibrium (e.g., expansion of forest into grasslands, expansion of tall grasses). The tree-lines of the Himalaya are mainly formed by Abies spp., Betula utilis, Juniperus spp., Pinus wallichiana, Larix spp., Rhododendron campanulatum, and Sorbus spp. Field-based studies $[69,70]$ have revealed an increase in tree density that is stable but with potential for shifting, in addition to upward shifting of the tree-line in the Nepalese Himalayas.

Although geological substrate and soil properties are key factors determining the distribution of several terrestrial orchids, at least at the regional and local levels, the importance of these factors differs between species [60]. For example, variation in the preferences of bedrock type was found for alpine Dactylorhiza sambucina [60]. This is because the occurrence of high-montane species is generally more dependent on climate, especially temperature [71]. D. hatagirea can occur in a number of geological substrates. Parent material (soil properties) was identified as the only factor of intermediate importance for the occurrence of $D$. hatagirea in our study and therefore cannot be ignored.

In addition to abiotic factors, the potential distribution of $D$. hatagirea can be shaped by its interaction with other plant or animal species (e.g., plant-pollinator or/and plantmycorrhizal fungi interactions). Bhattarai et al. [46] claim that the distribution of $D$. hatagirea is associated with the occurrence of other plant species, such as Anemone demissa, Bistorta macrophylla, Chesneya nubigena, Morina nepalensis, and Morina polyphylla. At present, we are not able to predict how climate change will affect these plants and how the potential changes in the local flora will disturb distribution of the studied orchid. Moreover, D. hatagirea is self-compatible but it is not capable of selfing [72]. The reproduction requires an animal pollen vector (probably insects, similar to other Dactylorhiza species), however, to date no data on specific insects transferring pollinia have been reported. Due to the lack of information on the specific composition of $D$. hatagirea pollinators, we were not able to analyze the impact of climate change on studied orchid pollen vectors, as has been done for rare European orchids [40,41]. Because pollinators are also severely threatened by climate change and habitat destruction [73], all factors that will affect their distribution or activity can be potentially considered as serious threats for $D$. hatagirea. The other question regards the influence of climate change on mycorrhizal fungi, which are crucial for seedling development in all orchids. At present, we do not know how specific are the relationships of $D$. hatagirea with symbiotic fungi and the species composition of its mycorrhizal associations. Further studies are required not only to evaluate the future distribution of orchid symbionts, but also to improve possible reintroduction of this species.

Conservation efforts should be focused on areas that will be suitable for $D$. hatagirea occurrence in the future, as indicated in our study. Among suitable areas in 13 districts under current climate conditions, only the Dolpa region will be unchanged under future climate change. However, the new suitable areas will be extended towards Mugu and 
Humla districts. The local scale genetic diversity is also equally important in order to determine which areas host rare genotypes or high genetic variability, and are therefore especially worth of preservation [74]. D. hatagirea is a strictly protected species in Nepal and banned to local collection, trade, and processing [44]. Intensive ex situ mass propagation is likely to reduce the rhizome collection from nature and simultaneously meet the economic demand, and together with the now supported massive reintroductions might promote the survival of $D$. hatagirea [75].

In general, species distribution models identify a portion of a species' fundamental niche, which is determined by the specific set of environmental predictors used in the analyses [76]. However, the actual distribution is always determined by complex biotic and abiotic interactions (e.g., competition, symbioses), in addition to biogeographical limitations (e.g., dispersal ability, historical factors). In our case, we used a $1 \times 1 \mathrm{~km}$ grid. Thus, orchids may be able to survive even in areas that were identified as non-suitable in the scale we used. This might be caused by the existence of suitable micro-sites that cannot be identified when using coarser spatial resolution.

In contrast, in some cases, the outputs of species distribution models may overestimate the species distribution, which may be attributed to a poor set of predictors. Other factors that could cause such inconsistences are related to the vegetation succession. Even if vegetation types or formations are also expected to change due to climate change [69,70], predictions of these changes are very difficult and cannot be taken into consideration when we explore the effects of climate change on the distribution of a specific species. Moreover, the importance of vegetation succession is low in cases when the effects of climate change in grassland species (such as D. hatagirea) are considered, because forest establishment in an area is a much slower process compared to the upward shift of a grassland herbaceous plant $[69,70]$. Contrary to the grassland species, such changes would be very important in the case of plant species occurring within forests, as such species are expected to decline or become extinct if forests change or become smaller.

\section{Materials and Methods}

\subsection{Study Area}

The study areas were in 14 locations of 3 conservation areas, 4 protected areas, and two districts which were outside of the protected areas (Figure 13). We recorded the D. hatagirea in Api Nampa Conservation Area (Chamelia Valley of Darchula), Khaptad National Park (Khaptad valley), Rara National Park (Rara lake), Jumla district (Depalgaun, Patamara, and Chhumchaur), Shey Phoksundo National Park (Lower Dolpa), Annapurna Conservation Area (Lower Mustang, Upper Mustang, Upper Manang, Ghandruk-Deurali), Manang district (Bhimtang), Manaslu Conservation Area (Samagaun), and Sagarmatha National Park (Phortse). All of these locations are located in sub-alpine and alpine climates of the high mountains $(3000-5000 \mathrm{~m})$. The major forest consists of subalpine conifer forests $(<3000 \mathrm{~m})$, sub-alpine mixed forest dominated by Abies spectabilis and Betula utilis (>3500-4000 m), and alpine shrub and meadows dominated by dwarf rhododendrons and alpine herbs and grass (3000-5000 m). 


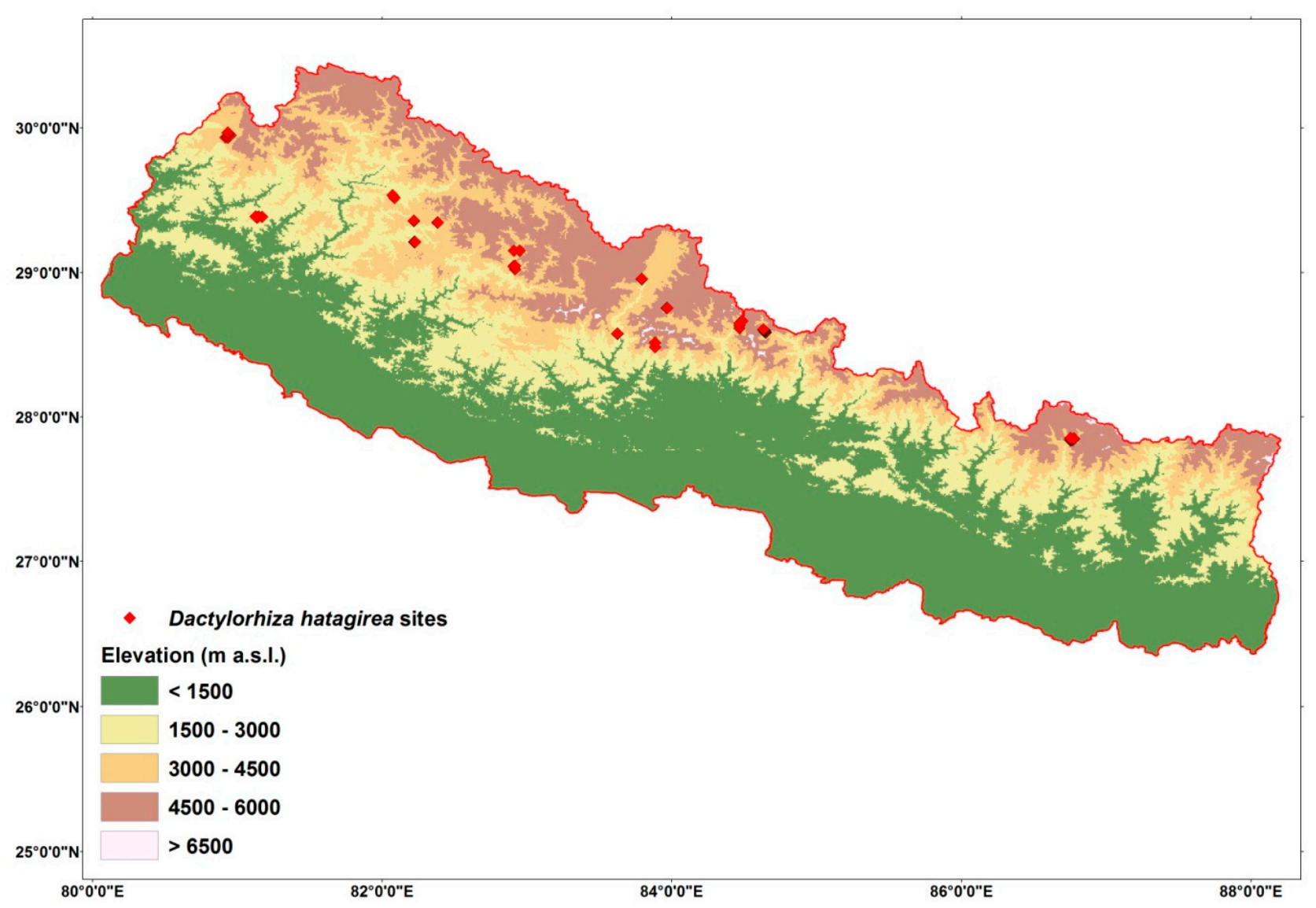

Figure 13. Map of the study area (Nepal) with the sites where D. hatagirea was found.

\subsection{Sampling and GPS Presence Locations}

Dactylorhiza hatagirea is a well-known medicinal plant which is commonly collected by local people [51-53]. Based on information obtained from collectors of this medicinal herb, we travelled along main trails used by people and herder trails in pasturelands in the 14 locations of the studied area with altitudinal range between 2200 and $5500 \mathrm{~m}$ to locate the presence of Dactylorhiza hatagirea. Once we recorded the presence areas, all presence GPS locations were recorded using a handheld device GARMIN GPSMAP. Moreover, we used distribution data of our research team obtained during field excursions conducted over the past 15 years. The main aim of our sampling was to record D. hatagirea in as many areas as possible. This is because our modelling analysis (described below) is based on ecological information obtained from a number of different sites and these data are used to predict the potential distribution of a species by calculating the habitat suitability across the landscape.

\subsection{Predictive Distribution Model}

To explore the potentially suitable area for Dactylorhiza hatagirea in Nepal under current and future climatic conditions, we applied ecological niche models generated by Maxent software version 3.4.1 [77,78].

Previous studies have used a variety of techniques and statistical methods have been used for the species distribution modelling [79-83]. They are based on resource selection function [84,85], generalized linear models [86], algorithmic modelling based on machine learning [87], and a maximum entropy model called Maxent [78]. Among these, currently the most often used method is Maxent because of its efficiency to handle complex interactions between response and predictor variables, and possibility to be integrated with GIS techniques [11]. 
Maxent is used in modelling species distributions and is characterized by a high predictive performance, even in the case of very small sample sizes $[61,62,88,89]$. The model uses presence-only occurrence data and a set of environmental variables, and by using the maximum entropy principle it computes habitat suitability values over the entire study area.

The distribution data used for the model were based on the sampling mentioned above. As the first step, we used 20 environmental explanatory variables. Nineteen of these were bioclimatic variables and one corresponded to the soil properties of the study area. The bioclimatic variables were downloaded from the WorldClim database [90] in a 30-sec resolution (approximately $1 \mathrm{~km}^{2}$ ), whereas the environmental layer corresponding to the soil properties was derived from the soil and terrain database (SOTER) for Nepal at a scale of 1:1,000,000 [91]. Although SOTER for Nepal was in vector format, the layer containing information about the parent material was converted to raster format at the same resolution and extent with the layers of the bioclimatic variables. Because specific bioclimatic variables are usually highly intercorrelated with others, we used ENMTools package [92] to calculate Pearson correlation coefficients for all pairwise interactions. To eliminate highly correlated variables, only one (i.e., the one with the higher percent contribution and training gain) was selected among any pair of those with a correlation coefficient $r>|0.80|[5,9]$.

In total, ten models were run with Maxent, and as suggested by Phillips and Dudík [71], we used the auto-features mode and the default settings. Maxent models were run using $80 \%$ of the sample point data and tested against the remainder. Because of the rather small number of occurrences of $D$. hatagirea, bootstrapping was used as a form of replication (test samples chosen randomly by sampling with replacement). We assessed model performance in the ENMTools package [92] using the Akaike information criterion (AICc) because it greatly outperforms BIC and AUC based methods, especially when sample size is small [93].

The future potential distribution of $D$. hatagirea and its habitat suitability in Nepal was predicted using 16 climate change scenarios, corresponding to the years 2050 (average for 2041-2060) and 2070 (average for 2061-2080). Specifically, for each period (2050 and 2070), four climate change models were chosen under the fifth Coupled Model Intercomparison Project (CMIP5). We chose the following climate change models: (a) the Hadley Earth System Model (HadGEM2-ES), (b) the Community Change System Model (CCSM4), (c) the Beijing Climate Centre Climate System Model (BCC-CSM1-1), and (d) the Model for Interdisciplinary Research on Climate (MIROC5). Two Representative Concentration Pathways (RCPs) were used for each period and each climate change model. The four different pathways that are available differ in the amounts of greenhouse gases that are expected to be emitted in the future. Beginning from the RCP2.6 to the RCP8.5, the emissions increase and thus RCP2.6 is a low emission scenario, whereas the RCP8.5 is a maximum emission scenario. The other two emission scenarios (RCP4.5 and RCP6.0) fall between these two extremes. In our analyses, we used the maximum greenhouse gas emission scenario (RCP8.5) and one out of the two medium greenhouse gas emission scenarios. Following Jiang et al. [94], and their results for China, the RCP4.5 was preferred instead of the other medium gas emission scenario (RCP6.0).

The outcome of the species distribution models is a continuous suitability map, which is usually converted into presence/absence data [76]. In the present study, the lowest presence threshold (equaling the minimum training presence) was used because it provides a reliable distribution of the studied species and can be better interpreted ecologically [95].

SDMtoolbox 2.3 for ArcGIS [96] was used to visualize changes in the distribution of suitable niches of the studied orchid and its pollinators caused by climate change in RCP4.5 and RCP8.5 climate change scenarios. To compare distribution models created for current climatic conditions with future models, all SDMs were converted into binary rasters and projected using the Goode homolosine projection. The presence threshold was set as equal to the minimum training presence. 


\section{Conclusions}

We evaluated the effect of predicted climate changes on the distribution of an endangered plant, $D$. hatagirea, in Nepal, which is already seriously threatened by illegal harvesting. The annual mean temperature (BIO1), seasonal nature of the precipitation (BIO15), and annual precipitation (BIO12) were identified as the most significant variables affecting the distribution of $D$. hatagirea. As indicated by our analyses, climate change constitutes a severe threat for this orchid. Our research predicts severe habitat loss in Nepal and, in the worst-case scenario, there are no suitable habitats for D. hatagirea. The coverage of suitable habitat will be zero by 2070 based on the HadGEM2-ES RCP4.5 and RCP8.5 scenarios. Based on the CCSM4 simulation, the decrease will be $71-81 \%$ by 2050 and $95-98 \%$ by 2070 . The most favorable scenario is that predicted by the BCC-CSM1-1 model, which predicts a reduction of $65-85 \%$. Surprisingly, the prediction of the occurrence of D. hatagirea based on the RCP.4.5 is lower in 2070 than that based on RCP8.5.

Other factors that could affect the future distribution of $D$. hatagirea are ecological interactions between this and other species, especially specific pollinators and mycorrhizal fungi. Alterations in the distributions of the orchid's insect pollinators could decrease its reproductive success and climate change may adversely affect its association with mycorrhizal fungi, resulting in poor seedling development.

In our opinion, conservation should focus on areas that this study indicates will be suitable for $D$. hatagirea in the future.

Author Contributions: Conceptualization, B.S., S.T., M.A.K., and P.K.; data curation, B.S., D.J.C., C.K., P.B. and N.K.S.; methodology, B.S. and S.T.; software, S.T. and M.A.K.; validation, B.S., S.T., M.A.K., and P.K.; formal analysis, B.S., S.T., M.A.K.; Investigation, B.S., writing — original draft preparation, B.S., S.T., N.K.S. and M.A.K.; writing-review and editing, B.S., S.T., M.A.K., and P.K.; project administration, B.S. All authors have read and agreed to the published version of the manuscript.

Funding: This research was funded by the Ministry of Education, Youth and Sports of CR within the CzeCOS program (Grant No. LM2018123), Danish Ministry of Foreign Affairs (Grant No. 13-07KU), The Rufford Foundation, UK (Rufford Small Grant: RSG-19960-1, RSG-11891-1, RSG-11881 and RSG-16864-2) and USAID-funded Hariyo Ban Program of WWF Nepal (EN02).

Data Availability Statement: The occurrence data of $D$. hatagirea presented in this study are available on request from the corresponding author.

Acknowledgments: Authors are thankful to the Department of National Parks and Wildlife Conservation (Nepal) and the National Trust for Nature Conservation/Annapurna Conservation Area Project (Nepal) for providing permission for this research and for conducting in the study areas. We thank Tony Dixon for editing the English. We would like to thank the Department of Plant Resources and all the community people for their continuous help and encourage. We thank the three anonymous reviewers for their careful and constructive comments on the manuscript.

Conflicts of Interest: The authors declare no conflict of interest. The funders had no role in the design of the study; in the collection, analyses, or interpretation of data; in the writing of the manuscript, or in the decision to publish the results.

\section{References}

1. Intergovernmental Panel on Climate Change. Part B: Regional Aspects. Contribution of Working Group II to the Fifth Assessment Report of the Intergovernmental Panel on Climate Change. In Climate Change 2014: Impacts, Adaptation, and Vulnerability; Barros, V.R., Field, C.B., Dokken, D.J., Mastrandrea, M.D., Mach, K.J., Bilir, T.E., Chatterjee, M., Ebi, K.L., Estrada, Y.O., Genova, R.C., Eds.; Cambridge University Press: Cambridge, UK; New York, NY, USA, 2014; pp. 1-669.

2. Hanski, I.; Zurita, G.A.; Bellocq, M.I.; Rybicki, J. Species-fragmented area relationship. Proc. Natl. Acad. Sci. USA 2013, 110, 12715-12720. [CrossRef] [PubMed]

3. Qin, A.; Liu, B.; Guo, Q.; Bussmann, R.W.; Ma, F.; Jian, Z.; Xu, G.; Pei, S. Maxent modeling for predicting impacts of climate change on the potential distribution of Thuja sutchuenensis Franch., an extremely endangered conifer from southwestern China. Glob. Ecol. Conserv. 2017, 10, 139-146. [CrossRef]

4. Antúnez, P.; Suárez-Mota, M.E.; Valenzuela-Encinas, C.; Ruiz-Aquino, F. The potential distribution of tree species in three periods of time under a climate change scenario. Forests 2018, 9, 628. [CrossRef] 
5. Xu, X.; Zhang, H.; Yue, J.; Xie, T.; Xu, Y.; Tian, Y. Predicting shifts in the suitable climatic distribution of walnut (Juglans regia L.) in China: Maximum entropy model paves the way to forest management. Forests 2018, 9, 103.

6. Pramanik, M.; Paudel, U.; Mondal, B.; Chakraborti, S.; Deb, P. Predicting climate change impacts on the distribution of the threatened Garcinia indica in the Western Ghats, India. Clim. Risk Manag. 2018, 19, 94-105. [CrossRef]

7. Zhang, L.; Jing, Z.; Li, Z.; Liu, Y.; Fang, S. Predictive modeling of suitable habitats for Cinnamomum Camphora (L.) presl using maxent model under climate change in China. Int. J. Environ. Res. 2019, 16, 3185. [CrossRef] [PubMed]

8. Cotrina Sánchez, D.A.; Barboza Castillo, E.; Rojas Briceño, N.B.; Oliva, M.; Torres Guzman, C.; Amasifuen Guerra, C.A.; Bandopadhyay, S. Distribution Models of Timber Species for Forest Conservation and Restoration in the Andean-Amazonian Landscape, North of Peru. Sustainability 2020, 12, 7945. [CrossRef]

9. Gilani, H.; Arif Goheer, M.; Ahmad, H.; Hussain, K. Under predicted climate change: Distribution and ecological niche modelling of six native tree species in Gilgit-Baltistan, Pakistan. Ecol. Indic. 2020, 111, 106049. [CrossRef]

10. Rojas, N.B.; Cotrina, D.A.; Castillo, E.B.; Oliva, M.; Salas, R. Current and Future Distribution of Five Timber Forest Species in Amazonas, Northeast Peru: Contributions towards a Restoration Strategy. Diversity 2020, 12, 305. [CrossRef]

11. Guo, Y.; Wei, H.; Lu, C.; Gao, B.; Gu, W. Predictions of potential geographical distribution and quality of Schisandra sphenanthera under climate change. PeerJ 2016, 4, e2554. [CrossRef]

12. Rana, S.K.; Rana, H.K.; Ghimire, S.K.; Shrestha, K.K.; Ranjitkar, S. Predicting the impact of climate change on the distribution of two threatened Himalayan medicinal plants of Liliaceae in Nepal. J. Mt. Sci. 2017, 14, 558-570. [CrossRef]

13. Bai, Y.; Wei, X.; Li, X. Distributional dynamics of a vulnerable species in response to past and future climate change: A window for conservation prospects. PeerJ 2018, 6, e4287. [CrossRef] [PubMed]

14. Abolmaali, S.M.R.; Tarkesh, M.; Bashari, H. Maxent modeling for predicting suitable habitats and identifying the effects of climate change on a threatened species, Daphne mucronata, in central Iran. Ecol. Inform. 2018, 43, 116-123. [CrossRef]

15. You, J.; Qin, X.; Ranjitkar, S.; Lougheed, S.C.; Wang, M.; Zhou, W.; Ouyang, D.; Zhou, Y.; Xu, J.; Zhang, W.; et al. Response to climate change of montane herbaceous plants in the genus Rhodiola predicted by ecological niche modelling. Sci. Rep. 2018, 8, 5879. [CrossRef]

16. Zhao, Q.; Li, R.; Gao, Y.; Yao, Q.; Guo, X.; Wang, W. Modeling impacts of climate change on the geographic distribution of medicinal plant Fritillaria cirrhosa D. Don. Plant Biosyst. 2018, 152, 349-355. [CrossRef]

17. Abdelaal, M.; Fois, M.; Fenu, G.; Bacchetta, G. Using Maxent modeling to predict the potential distribution of the endemic plant Rosa arabica Crép. Egypt. Ecol. Inform. 2019, 50, 68-75. [CrossRef]

18. Yuan, H.S.; Wei, Y.L.; Wang, X.G. Maxent modeling for predicting the potential distribution of Sanghuang, an important group of medicinal fungi in China. Fungal Ecol. 2015, 17, 140-145. [CrossRef]

19. Shrestha, U.B.; Sharma, K.P.; Devkota, A.; Siwakoti, M.; Shrestha, B.B. Potential impact of climate change on the distribution of six invasive alien plants in Nepal. Ecol. Indic. 2018, 95, 99-107. [CrossRef]

20. Kariyawasam, C.S.; Kumar, L.; Ratnayake, S.S. Invasive plant species establishment and range dynamics in Sri Lanka under climate change. Entropy 2019, 21, 571. [CrossRef]

21. Ongaro, S.; Martellos, S.; Bacaro, G.; Agostini, A.D.; Cogoni, A.; Cortis, P. Distributional pattern of Sardinian orchids under a climate change scenario. Community Ecol. 2018, 19, 223-232. [CrossRef]

22. Cavaliere, C. The effects of climate change on medicinal and aromatic plants. Herb. Gram. 2008, 81, 44-57.

23. Kelly, A.E.; Goulden, M.L. Rapid shifts in plant distribution with recent climate change. Proc. Natl. Acad. Sci. USA 2008, 105, 11823-11826. [CrossRef] [PubMed]

24. Chen, I.C.; Hill, J.K.; Ohlemüller, R.; Roy, D.B.; Thomas, C.D. Rapid range shifts of species associated with high levels of climate warming. Science 2011, 333, 1024-1026. [CrossRef] [PubMed]

25. Lenoir, J.; Svenning, J.C. Latitudinal and elevational Range Shifts under contemporary Climate Change. In Encyclopedia of Biodiversity, 2nd ed.; Levin, S., Ed.; Elsevier: Amsterdam, The Netherlands, 2013; pp. 599-611.

26. Suggitt, A.J.; Platts, P.J.; Barata, I.M.; Bennie, J.; Burgess, M.D.; Bystriakova, N.; Duffield, S.; Ewing, S.R.; Gillingham, P.K.; Harper, A.B.; et al. Conducting robust ecological analyses with climate data. Oikos 2017, 126, 1533-1541. [CrossRef]

27. Štípková, Z.; Romportl, D.; Černocká, V.; Kindlmann, P. Factors associated with the distributions of orchids in the Jeseníky Mountains, Czech Republic. Eur. J. Environ. Sci. 2017, 7, 135-145. [CrossRef]

28. La Sorte, F.A.; Jetz, W. Projected range contractions of montane biodiversity under global warming. Proc. R. Soc. Lond. 2010, 277, 3401-3410. [CrossRef] [PubMed]

29. Intergovernmental Panel on Climate Change. The Physical Science Basis. Contribution of Working Group I to the Fourth Assessment Report of the Intergovernmental Panel on Climate Change. In Climate Change 2007; Solomon, S., Qin, D., Manning, M., Chen, Z., Marquis, M., Averyt, K.B., Tignor, M., Miller, H.L., Eds.; Cambridge University Press: Cambridge, UK; New York, NY, USA, 2007; pp. 1-996.

30. Shrestha, U.B.; Gautam, S.; Bawa, K.S. Widespread climate change in the Himalayas and associated changes in local ecosystems. PLoS ONE 2012, 7, e36741. [CrossRef]

31. Xu, J.; Grumbine, R.E.; Shrestha, A.; Eriksson, M.; Yang, X.; Wang, Y.; Wilkes, A. The melting Himalayas: Cascading effects of climate change on water, biodiversity, and livelihoods. Conserv. Biol. 2009, 23, 520-530. [CrossRef]

32. González-Salazar, C.; Stephens, C.R.; Marquet, P.A. Comparing the relative contributions of biotic and abiotic factors as mediators of species' distributions. Ecol. Model. 2013, 248, 57-70. [CrossRef] 
33. Telwala, Y.; Brook, B.W.; Manish, K.; Pandit, M.K. Climate-induced elevational range shifts and increase in plant species richness in a Himalayan biodiversity epicentre. PLOS ONE 2013, 8, e57103. [CrossRef]

34. Thomas, C.D.; Cameron, A.; Green, R.E.; Bakkenes, M.; Beaumont, L.J.; Collingham, Y.C.; Erasmus, B.F.N.; de Siqueira, M.F.; Grainger, A.; Hannah, L.; et al. Extinction risk from climate change. Nature 2004, 42, 145-148. [CrossRef] [PubMed]

35. Dixon, K.W.; Kell, S.P.; Barrett, R.L.; Cribb, P.J. Orchid Conservation; Sabah Natural History Publications: Kota Kinabalu, Malaysia, 2003.

36. Sharma, P.K.; Sharita, S.; Prell, J. Dactylor hizahatagirea (D. Don) Soo-A West Himalayan Orchid in Peril. Curr. Sci. 2005, 89, 610-612.

37. Swarts, N.D.; Dixon, K.W. Terrestrial orchid conservation in the age of extinction. Ann. Bot. 2009, 104, 543-556. [CrossRef]

38. Aggarwal, S.; Zettler, L.W. Reintroduction of an endangered terrestrial orchid Dactylorhiza hatagirea (D. Don) Soo, assisted by symbiotic seed germination: First report from the Indian subcontinent. Nat. Sci. 2010, 8, 139-145.

39. Duffy, K.J.; Johnson, S.D. Specialized mutualisms may constrain the geographical distribution of flowering plants. Proc. R. Soc. $B$ 2017, 284, 1841. [CrossRef] [PubMed]

40. Kolanowska, M.; Jakubska-Busse, A. Is the lady's-slipper orchid (Cypripedium calceolus) likely to shortly become extinct in Europe?-Insights based on ecological niche modelling. PLoS ONE 2020, 15, e0228420.

41. Tsiftsis, S.; Djordjević, V. Modelling sexually deceptive orchid species distributions under future climates: The importance of plant-pollinator interactions. Sci. Rep. 2020, 10, 10623. [CrossRef]

42. Conservation Assessment and Management Plan. Executive Summary Report of the Conservation Assessment and Management Plan (CAMP) of the Biodiversity Conservation Prioritization Project on Selected Medicinal Plants of Northern, North-Eastern and Central India. Available online: http:/ / msubiology.info/vesna/nauka/pillon2006.pdf (accessed on 29 March 2014).

43. Samant, S.S.; Dhar, U.; Rawal, R.S. (Eds.) Himalayan Medicinal Plants-Potential and Prospects; Gyanodaya Prakashan: Nainital, India, 2001.

44. Go, N. Protected Plants of Nepal: Its amendments. Kathmandu, Nepal: Ministry of Forests and Soil Conservation. Nepal Gaz. 2011, 60, 38-45.

45. Raskoti, B.B. The Orchids of Nepal; Bhakta Bahadur Raskoti and Rita Ale: Kathmandu, Nepal, 2009.

46. Bhattarai, P.; Pandey, B.; Gautam, K.R.; Chhetri, R. Ecology and Conservation Status of Threatened Orchid Dactylorhiza hatagirea (D. Don) Soo in Manaslu Conservation Area, Central Nepal. Am. J. Plant Sci. 2014, 5, 3483-3491. [CrossRef]

47. Shrestha, B.; Kindlmann, P.; Jnawali, S.R. Interactions between the Himalayan tahr, livestock and snow leopards in the Sagarmatha National Park. In Himalayan Biodiversity in the Changing World; Kindlmann, P., Ed.; Springer: Dordrecht, The Netherlands, 2012; pp. 115-145.

48. Khadka, C.; Hammet, A.; Singh, A.; Balla, M.; Timilsina, Y. Ecological status and diversity indices of Panchaule (Dactylorhiza hatagirea) and its associates in Lete village of Mustang district, Nepal. Banko Janakari 2016, 26, 45-52. [CrossRef]

49. Chhetri, H.B.; Gupta, V.N.P. A survey of non-timber forest products (NTFPS) in Upper Mustang. Sci. World 2007, 5, 89-94. [CrossRef]

50. International Union for Nature Conservation Nepal. National Register of Medicinal and Aromatic Plants; International Union for Nature Conservation Nepal: Kathmandu, Nepal, 2004.

51. Pant, S.; Tsewang, R. Dactylorhiza hatagirea: A high value medicinal orchid. J. Med. Plant Res. 2012, 6, $3522-3524$.

52. Chamoli, K.P.; Sharan, H. Ethno-medicinal properties of Dactylorhiza hatagirea in higher Himalayan villages of Rudraprayag district of Uttarakhand. J. Mt. Res. 2019, 14, 85-88.

53. Thakur, M.; Dixit, V.K. Aphrodisiac Activity of Dactylorhiza hatagirea (D. Don) Soo in Male Albino Rats. Evid. Based Complementary Altern. Med. 2007, 4, 29-31. [CrossRef] [PubMed]

54. Popli, D. Elicitation of Dactylorhin-E and Studying Anti-Cancerous Potential of Dactylorhiza Hatagirea (D. Don). Master's Dissertation, Biotechnology, Jaypee University of Information and Technology, Waknaghat, India, 2017.

55. Kindlmann, P.; Kull, T.; Whigham, D.F.; Willems, J. Ecology and population dynamics of terrestrial orchids: An introduction. Folia Geobot. 2006, 41, 1-2. [CrossRef]

56. Dubuis, A.; Pottier, J.; Rion, V.; Pellissier, L.; Theurillat, J.P.; Guisan, A. Predicting spatial patterns of plant species richness: A comparison of direct macroecological and species stacking approaches. Divers. Distrib. 2011. [CrossRef]

57. Kaky, E.; Gilbert, F. Using species distribution models to assess the importance of Egypt's protected areas for the conservation of medicinal plants. J. Arid Environ. 2016, 135, 140-146. [CrossRef]

58. Pandey, B.; Timilsina, A.; Pandey, B.; Thapa, C.L.; Nepali, K.B.; Neupane, P.; Thapa, R.; Gaire, S.K.; Siwakoti, M. Peoples' perception and conservation of Dactylorhiza hatagirea (D. Don) Soó in Manaslu Conservation Area, Central Nepal. Am. J. Plant Sci. 2016, 7, 1662-1672. [CrossRef]

59. Kunwar, R.M.; Rimal, B.; Sharma, H.P.; Poudel, R.C.; Pyakurel, D.; Tiwari, A.; Magar, S.T.; Karki, G.; Bhandari, G.S.; Pandey, P.; et al. Distribution and habitat modeling of Dactylorhiza hatagirea (D. Don) Soo, Paris polyphylla Sm. and Taxus species in Nepal Himalaya. J. Appl. Res. Med. Aromat. Plants 2021, 20, 100274.

60. Djordjević, V.; Tsiftsis, S. The Role of Ecological Factors in Distribution and Abundance of Terrestrial Orchids. In Orchids Phytochemistry, Biology and Horticulture; Mérillon, J.M., Kodja, H., Eds.; Springer: Cham, Switerland, 2020; pp. 1-71.

61. Pearson, R.G.; Raxworthy, C.; Nakamura, M.; Peterson, A. Predicting species distributions from small numbers of occurrence records: A test case using cryptic geckos in Madagascar. J. Biogeogr. 2006, 34, 102-117. [CrossRef] 
62. Hernandez, P.A.; Graham, C.H.; Master, L.L.; Albert, D.L. The effect of sample size and species characteristics on performance of different species distribution modelling methods. Ecography 2006, 29, 773-785. [CrossRef]

63. Bhattarai, S.; Chaudhary, R.P.; Taylor, R.S.L. Prioritization and trade of ethnomedicinal plants by the people of Manang district, central Nepal. In Vegetation and Society: Their Interaction in the Himalayas; Chaudhary, R.P., Subedi, B.P., Vetaas, O., Eds.; Tribhuvan University: Kathmandu, Nepal; University of Bergen Norway: Bergen, Norway, 2002; pp. 151-169.

64. Subedi, A.; Kunwar, B.; Choi, Y.; Dai, Y.; van Andel, T.; Chaudhary, R.P.; de Boer, H.J.; Gravendeel, B. Collection and trade of wild-harvested orchids in Nepal. J. Ethnobiol. Ethnomed. 2013, 9, 64. [CrossRef] [PubMed]

65. Thakur, R.B.; Yadav, R.P.; Thakur, N.P. Enumerating the status of orchid species of Makawanpur district. Hamro Kalpabricha 2010, $20,1-18$.

66. Zaniewski, A.E.; Lehman, A.; Overton, J. Predicting species spatial distributions using presence-only data: A case study of native New Zealand ferns. Ecol. Model. 2002, 157, 261-280. [CrossRef]

67. de Mesquita, C.P.B.; Tillmann, L.S.; Bernard, C.D.; Katherine, C.R.; Noah, P.M.; Suding, K.N. Topographic heterogeneity explains patterns of vegetation response to climate change (1972-2008) across a mountain landscape, Niwot Ridge, Colorado. Arct. Antarct. Alp. Res. 2018, 50, e1504492. [CrossRef]

68. Amagai, Y.; Kudo, G.; Sato, K. Changes in alpine plant communities under climate change: Dynamics of snow-meadow vegetation in northern Japan over the last 40 years. Appl. Veg. Sci. 2018, 21, 561-571. [CrossRef]

69. Shrestha, K.B.; Hofgaard, A.; Vandvik, V. Recent treeline dynamics are similarbetween dry and mesic areas of Nepal, central Himalaya. J. Plant Ecol. 2015, 8, 347-358. [CrossRef]

70. Gaire, N.P.; Koirala, M.; Bhuju, D.R.; Carrer, M. Site- and species-specific treeline responses to climatic variability in eastern Nepal Himalaya. Dendrochronologia 2017, 41, 44-56. [CrossRef]

71. Sakai, A.; Larcher, W. Frost Survival of Plants: Responses and Adaptation to Freezing Stress; Springer: Berlin, Germany, 1987.

72. Thakur, D.; Rathore, M.; Sharma, M.K.; Chawla, A. Enhanced reproductive success revealed key strategy for persistence of devastated populations in Himalayan food-deceptive orchid, Dactylorhiza hatagirea. Plant Species Biol. 2018, 33, 191-202. [CrossRef]

73. Memmott, J.; Craze, P.G.; Waser, N.M.; Price, M.V. Global warming and the disruption of plant-pollinator interactions. Ecol. Lett. 2007, 10, 710-717. [CrossRef]

74. Kosanic, A.; Anderson, K.; Frère, C.H.; Harrison, S. Regional vegetation change and implications for local conservation: An example from West Cornwall (United Kingdom). Glob. Ecol. Conserv. 2015, 4, 405-413. [CrossRef]

75. Magar, M.; Dhital, S.; Yamada, T.; Pun, U. Dactylorhiza hatagirea: A Critical Issue for Research and Development in Nepal. Nepal J. Sci. Technol. 2020, 19, 26-38. [CrossRef]

76. Pearson, R.G. Species' distribution modeling for conservation educators and practitioners. Lessons Conserv. $2010,3,54-89$.

77. Phillips, S.J.; Dudík, M. Modeling of species distributions with Maxent: New extensions and a comprehensive evaluation. Ecography 2008, 31, 161-175. [CrossRef]

78. Phillips, S.J.; Anderson, R.P.; Dudík, M.; Schapire, R.E.; Blair, M.E. Opening the black box: An open-source release of Maxent. Ecography 2017, 40, 887-893. [CrossRef]

79. Corsi, F.; De Leeuw, J.; Skidmore, A. Modelling species distribution with GIS. In Research Techniques in Animal Ecology; Controversies and Consequences; Boitan, L., Fuller, T.K., Eds.; Columbia University Press: New York, NY, USA, 2000; pp. $389-434$.

80. Elith, J.; Graham, C.H.; Anderson, R.P.; Dudik, M.; Ferrier, S.; Guisan, A.; Hijmans, R.J.; Huettmann, F.; Leathwick, J.R.; Lehmann, A.; et al. Novel methods improve prediction of species' distributions from occurrence data. Ecography 2006, 29, 129-151. [CrossRef]

81. Guisan, A.; Zimmerman, N.E. Predictive habitat distribution models in ecology. Ecol. Model. 2000, 135, 147-186. [CrossRef]

82. Scott, J.M.; Heglund, P.J.; Morrison, M.L.; Haufler, J.B.; Raphael, M.G.; Wall, W.A.; Samson, F.B. (Eds.) Predicting Species Occurrences: Issues of Scale and Accuracy; Island Press: Washington, DC, USA, 2002.

83. Franklin, J. Mapping Species Distributions: Spatial Inference and Prediction; Cambridge University Press: Cambridge, UK, 2009.

84. Boyce, M.; McDonald, L. Relating populations to habitats using resource selection functions. Trends Ecol. Evol. 1999, 14, $268-272$. [CrossRef]

85. Manly, B.F.J.; McDonald, L.L.; Thomas, D.L.; MacDonald, T.L.; Erickson, W.P. (Eds.) Resource selection by animals. In Statistical Design and Analysis for Field Studies, 2nd ed.; Kluwer Academic Publisher: London, UK, 2002.

86. McCullagh, P.; Nelder, J.A. Generalized Linear Models, 2nd ed.; Chapman and Hall/CRC: Washington, DC, USA, 1989.

87. Ripley, B.D. Pattern Recognition and Neural Networks; Cambridge University Press: Cambridge, UK, 1996.

88. Elith, J.; Leathwick, J. The contribution of species distribution modelling to conservation prioritization. In Spatial Conservation Prioritization. Quantitative Methods \& Computational Tools; Moilanen, A., Wilson, A.K., Possingham, H.P., Eds.; Oxford University Press Inc.: New York, NY, USA, 2009; pp. 70-93.

89. David, O.A.; Akomolafe, G.F.; Onwusiri, K.C.; Fabolude, G.O. Predicting the distribution of the invasive species Hyptis suaveolens in Nigeria. Eur. J. Environ. Sci. 2020, 10, 98-106. [CrossRef]

90. Fick, S.E.; Hijmans, R.J. WorldClim 2: New 1-km spatial resolution climate surfaces for global land areas. Int. J. Clim. 2017, 37, 4302-4315. [CrossRef]

91. Dijkshoorn, J.A.; Huting, J.R.M. Soil and Terrain Database for Nepal; ISRIC—World Soil Information: Wageningen, The Netherlands, 2009; Available online: http:/ / www.isric.org (accessed on 9 April 2019). 
92. Warren, D.L.; Glor, R.E.; Turelli, M. ENMTools: A toolbox for comparative studies of environmental niche models. Ecography 2010, 33, 607-611. [CrossRef]

93. Warren, D.L.; Seifert, S.N. Ecological niche modeling in Maxent: The importance of model complexity and the performance of model selection criteria. Ecol. Appl. 2011, 21, 335-342. [CrossRef] [PubMed]

94. Jiang, H.; Liu, T.; Li, L.; Zhao, Y.; Pei, L.; Zhao, J. Predicting the potential distribution of Polygala tenuifolia Willd. under climate change in China. PLoS ONE 2016, 11, e0163718. [CrossRef] [PubMed]

95. Freeman, E.A.; Moisen, G.G. A comparison of the performance of threshold criteria for binary classification in terms of predicted prevalence and kappa. Ecol. Model. 2008, 217, 48-58. [CrossRef]

96. Kremen, C.A.; Cameron, A.; Moilanen, S.J.; Phillips, C.D.; Thomas, H.; Beentje, J.; Dransfield, B.L.; Fisher, F.; Glaw, T.C.; Good, G.J.; et al. Aligning conservation priorities across taxa in Madagascar with high-resolution planning tools. Science 2008, 320, 222-226. [CrossRef] [PubMed] 